doi:10.29285/actapinteriana.2021.7.69

\title{
A magisztérium teológiai témájának központi helye és fejlődése Avery Dulles bíboros életmüvében
}

\author{
Bagyinszki Péter Ágoston OFM \\ Sapientia Szerzetesi Hittudományi Főiskola, 1052 Budapest, Piarista köz 1. \\ bagyinszki.agoston@sapientia.hu
}

Bagyinszki A. (2021): A magisztérium teológiai témájának központi helye és fejlödése Avery Dulles biboros életmüvében. The development and central role of Magisterium, as a subject of theology, as observed in the legacy of Cardinal Avery Dulles. Acta Pintériana, 7: 69-107.

\begin{abstract}
The article analyzes a special part of the diverse theological oeuvre of Cardinal-Deacon Avery Dulles (1918-2008), focusing on the role of the Magisterium. The American theologian considers „the pluralistic model of ecclesiastical authority" to be the most essential aspect of authority. Christ is the primary divine authority and source of all secondary authorities: the Sacred Scripture, the Holy Tradition, the sense of faith of believers, the pastoral office (Magisterium), and the theologians. The first part of the article starts with a brief description of Avery Dulles's childhood, youth, family background, and studies. Then, the author outlines the three periods of Dulles's professional life strictly from the perspective of his theology of authority: why did he elaborate it, what impacts he had that moved him in this direction, and what were the most important milestones of this oeuvre. It was Dulles himself who summarised and revisited the main conclusions of his thought concerning the theology of the Magisterium in a short monograph at the end of his life. The last part of this article places the Magnum Opus in the context of the entire oeuvre that proves the maturity of the old cardinal's synthesis.
\end{abstract}

\section{Bevezetés}

Jézus Krisztusról, a Mesterről már tanítványainak első generációja feljegyezte, hogy egyedülálló tekintéllyel (exusia) tanított, nem csupán úgy, mint az írástudók (vö. Mt 7,29; Mk 1,22; Lk 4,32). Ezzel az egyház életében később sokrétủen intézményesedett mester-tanítvány viszonnyal összefüggésben jegyzi meg Avery Dulles:

„A keresztény ember helyes kérdése nem az, hogy elfogadjon-e autoritást maga fölött, hanem hogy miképpen alakitsa ki a megfelelö viszonyt a felismert autoritás-intézményekkel. Sok keresztény elköveti azt a hibát, hogy bizonyos tekintélyeket semmibe vesz, míg másokat abszolutizál."

(DULLES 1977a, pp. 94-95)

Az amerikai teológus tanítványságra fókuszált tekintélyelméletének lényegét - ennek a központi belátásnak megfelelően - abban foglalhatjuk össze, hogy Jézus Krisztus „elsődleges istenemberi autoritását” az egyház életében intézmények ,pentádja” (öt elemből álló strukturált csoportja) közvetíti, amely „másodlagos autoritások” egymással is összetett interakcióban állnak: a Szentírás, a Szenthagyomány, a hívők testületének hitérzéke, a teológusok akadémikus autoritása, valamint a hivatali tekintélyek dinamikus összjátéka. Mindez a teológiai episztemológia szempontjából olyan 
jelentős, hogy a csoport egyetlen tagja sem töltheti be az Istentől neki rendelt szerepet a csoport többi tagjának sajátos közvetítői hozzájárulása nélkül, avagy a maga egyedi szerepéből kilépve. ${ }^{1}$ Dulles szerint az „inkarnatórikus” keresztény hit, a mester-tanítvány viszony egyedülálló jellegzetességeire nyílik rálátás a különböző tekintélyformák e koronként kissé átrendeződő, lényegében mégis azonos konfigurációján keresztül.

Az amerikai teológus ezt az alapgondolatot negatív módon is megfogalmazza: a teológiatörténetben mindig zavar forrása lett, ha az egyes autoritás-intézményeket egymástól szigorúan elszigetelve szemlélték, mintegy „abszolutizálva” azokat (lásd sola Scriptura, sola traditione, solo magisterio stb.). Szintén nem adott teljes horizontot a teológiai episztemológia problematikájának tárgyalásához, ha csak e tekintélyformák „diádjaival” foglalkoztak (lásd például a Szentírás és Szenthagyomány viszonyát érintő véget nem érő újkori vitákat). Még a „triádok” tárgyalása sem eredményez kompakt elméleti megoldásokat, legyen bár szó akár a Szentírás - Szenthagyomány - tanítóhivatal, akár a tanítóhivatal teológusok - hitérzék hármasokról. A katolikum hiteles megragadásához szükséges a teljes „pentád” strukturált dinamizmusának a tekintetbe vétele. Dulles jelen tanulmányban vizsgált magisztériumteológiájának éppen abban rejlik a hiteles egyedisége, hogy kontextualizált áttekintést kapunk a hivatali tekintély egyházi szolgálatáról: az autoritásformák sokrétü interakcióinak hátterében pedig mindig kirajzolódik az elsődleges isteni autoritás, amelynek a másodlagos jelentőségü üdvtörténeti intézmények csak közvetítöi.

A jezsuita teológus az „episztémikus autoritás” egyház szervezeti kultúráján belüli (ad intra) vizsgálatán túl kitér a tekintélyi struktúrák müködésének külső szempontú (ad extra) elemzésére is. A két szempont közötti alapvető kapcsolatot az egyház társadalmi tanítása maga tematizálja, miközben ugyanez a tanítás néhány területen megvilágítja a „befelé” és „kifelé” érvényesnek tekintett keresztény normák hangsúlykülönbségeit is. Például az „autokratább” ad intra megközelítés másképp súlyozza a jogilag leírt „formális tekintély” és a kompetenciák függvényében megvalósuló „hatékony tekintély” viszonyát, mint a „demokratikusabb” ad extra megközelítés. Hangsúlyaiban szintén eltér a két megközelítés a „szubszidiaritás elvének”, illetve a „hatalmi ágak szétválasztásának” elvi és gyakorlati megvalósításaiban. Életpályája során Dulles a fenti kérdések „posztkonciliáris szindrómához” köthető kritikusabb tárgyalásától az egyház jelen gyakorlata iránt megértőbb szemléletmód felé haladt, miközben mindvégig az átpolitizált szélsőségeket elkerülő, teológiailag megalapozott középutas egyensúlykeresésre törekedett.

E tanulmány a bejárt életút összefüggésében helyezi el Dulles „kapcsolatiságba ágyazott tekintélyfelfogásának" a fejlődő gondolatrendszerét: egy biográfiai bevezető után három különböző egyetemhez kapcsolódó három pályaszakasz elemzésén keresztül mutatja be, hogy a jezsuita teológusban miként kristályosodott ki kutatási projektjének központi kérdése, illetve milyen lépéseken keresztül formálódott meg e kérdésre válaszként a szerző „pluralisztikus tekintélyelmélete”. A magisztérium teológiájával kapcsolatos főbb eredményeit élete végén maga Dulles foglalta össze és tárgyalta újra egy rövid monográfiában. A tanulmány utolsó része az egész életmü kontextusában helyezi el a Magnum Opus anyagát, amely az idős bíborosban megszülető érett szintézis tanúbizonysága. Jelen összegzésnek különös aktualitást ad, hogy Dulles II. János Pál pápától 2001-ben, pont két évtizeddel ezelőtt kapta meg a bíborosi kalapot nagyívü teológusi életművének elismeréseként.

Érdemes megjegyezni, hogy ez a megállapítás a II. Vatikáni Zsinat DV 10c-ben található gondolatának általánosítása, amely logikailag magában foglalja a szükebb értelmü zsinati kijelentést. 


\section{Családi gyökerek és apai örökség}

Avery Dulles 1918. augusztus 24-én született a New York állam területén található Auburnben, John Foster Dulles és Janet Avery harmadik, utolsó gyermekeként. ${ }^{2}$ A családnak erős presbiteriánus gyökerei voltak, Avery apai nagyapja (Rev. Allen Macy Dulles) felekezetének elismert lelkésze és teológusa volt. Dulles e tanulmányban vizsgált érdeklődési irányára erősen hatott, hogy családjában szép számmal voltak diplomaták és kiemelkedő közéleti szereplök, akik már korán fölkeltették a fiatalember érdeklődését társadalomfilozófiai és államtudományi kérdések iránt. Három rokona is az Egyesült Államok külügyminisztereként szolgált: apja, John Foster Dulles (Dwight Eisenhower elnök alatt); ükapja, John Watson Dulles (Benjamin Harrison elnök alatt); továbbá egy apai nagybácsi, Robert Lansing (Woodrow Wilson elnök alatt) (lásd CAREY 2010a, pp. 1-11).

Avery karakteres vallásos neveltetést kapott, de középiskolás évei alatt megingott hitében, amikor szülei Svájcba (Le Rosey Preparatory School) küldték tanulni (lásd uo. pp. 13-21). Már korai tanulmányai és utazásai felkeltették a tehetséges diák bölcsészeti érdeklődését, ám csak az Egyesült Államokba visszatérve (Choate Preparatory School, Connecticut) mutatkozott meg az ifjú későbbiekre nézve meghatározó filozófiai hajlama (lásd DULLES 2000c, pp. 72-82). Ekkoriban főleg szekuláris és materialista filozófiákkal ismerkedett, melynek során még Isten létének kérdésében is elbizonytalanodott. Érettségi után a Harvard Egyetemen folytatta tanulmányait, öntudatosan hátat fordítva apja alma materének, a Princeton Egyetemnek (vö. DULLES 1950 in O’BRIEN 1950, pp. 65-68).

Első bölcsész egyetemista éveiben olyan filozófiatörténeti kurzusokkal találkozott, amelyek fölkeltették érdeklődését a keresztény skolasztika iránt. Etienne Gilson és Jacques Maritain műveinek tanulmányozása bevezette ôt a katolikus hagyomány intellektuális gazdagságába (lásd DULLES 1998a, pp. 1, 13). A Harvard kötelező kurzusai keretében Dulles Platón és Arisztotelész szellemi örökségével is megismerkedett, melynek során különösen érdekesnek találta e klasszikus gondolkodók skolasztikusokhoz füződő kapcsolatának tanulmányozását. Érlelődő szellemi élete immár felszínesnek érzékelte a modern szekularisták agnosztikus gondolatvilágát. Első egyetemi évének végére ismét feléledt hite a szerető, személyes Istenben, akinek jelenléte betölti a világegyetemet (lásd CAREY 2010a, pp. 21-35).

Dulles katolizálásának útja azonban még három évig tartott, amely út számára az Újszövetség szorgalmas tanulmányozásával, Jézus alakjának és üzenetének kutatásával vette kezdetét. ${ }^{3}$ Dulles ebben az időszakban újra elkezdett protestáns templomokba járni, ám egyikben sem ,,találta meg a hiteles ragaszkodást Krisztus kinyilatkoztatott szavának egyedülálló tekintélyéhez (the unique authority of Christ's revealed word)" (DULLES 1950 in O'BRIEN 1950, p. 76). A katolikus klasszikusok és konvertita történetek olvasása keltette fel az érdeklődését a katolicizmus iránt, amelyre a környezetében megtapasztalt katolikus jámborság is további pozitív hatással volt. Mint „nagyreményű középkor kutató" (budding medievalist) (DULLES 1993 in WILLS 1993, p. 122), Dulles elsősorban intellektuális úton, a katolikus identitást hordozó hagyomány tanulmányozásán keresztül került egyre közelebb és közelebb a katolicizmushoz (vö. DULLES 1996a, p. 66). Nem elégedett meg a különböző keresztény prédikátorok és tanítók személyes állásfoglalásaival, tanúságtételével, hanem makacs következetességgel az egyház intézményes hitét kívánta megismerni. Ez az eltökéltség vezette öt el a katolizálásig (lásd CAREY 2010a, pp. 41-65; vö. DULLES 1991e, pp. 12-26). Transzformatív, átalakító

\footnotetext{
Avery Dulles családi hátteréről lásd MosLEY 1978.

Nagyon tanulságos Dulles saját megtéréstörténetének összefüggésében olvasni azt a félévszázaddal később írott cikkét, amelyben az „elköteleződő vagy bevonódó megismerésre” (vs. elkötelezetlen vagy bevonódásmentes) és „a hit kognitív dimenziójára” ad elmélyült reflexiót, az általa egzisztenciálisan is bejárt intellektuális út metafizikai, történeti tudatossággal kapcsolatos, vallástudományi, és végül teológiai fázisait szem előtt tartva (DULLES 2015, pp. 163-172).
} 
erejü élmény volt számára, az Ige egyházából érkező konvertita számára az Eucharisztiának, a szentmise szimbólumokban gazdag rituális világának - és azon keresztül az egyház szakramentális valóságának megtapasztalása (lásd DULLES 1996a, pp. 62-64; vö. CAREY 2010a, pp. 547-549; DULLES 2005b, pp. 100-111).

Dulles római katolikus befogadási szertartására 1940. november 26-án került sor. Az ezt követő időszakban különböző katolikus egyetemi és ifjúsági szervezetekben vállalt aktív szerepet (pl. a St. Benedict Centerben), miközben átélte első lelkesítő akadémiai sikereit. Végzős egyetemistaként, 1940ben, mielött a Harvard Law Schoolban jogi irányban folytatta tanulmányait, Pico della Mirandoláról írt szakdolgozata díjat nyert és ünnepelt publikációként hozott elismerést szerzőjének (DULLES 1941; vö. CAREY 2010a, pp 35-40). Miután azonban 1941. december 7-én az Egyesült Államokat a Pearl Harbori támaszpontján támadás érte, és maga is aktív szereplőként kényszerült belépni a II. világháborúba, Dulles is megszakította másodéves jogi tanulmányait és - több évfolyamtársával, köztük John Fitzgerald Kennedyvel együtt - bevonult a haditengerészethez, ahol közel öt éven keresztül teljesített szolgálatot (lásd uo. pp. 66-93). A háború elvonultával Dulles belevetette magát az egyházatyák tanulmányozásába, amely tapasztalat később is nagyban segítette őt teológusi érlelődésében (vö. uo. pp. 88-90).

1946 augusztusában Dulles jelentkezett a Jézus Társaságba, és a következő éveket az intenzív jezsuita alapképzéssel töltötte (lásd uo. pp. 94-136). Fél évszázad múltán visszatekintve Dulles azt emeli ki a jezsuita lelkiség iránti vonzalmának okát keresve, hogy az képes dialektikusan integrálni az istenélmény intrinzikus (bensőleg megtapasztalt) és extrinzikus (objektíven egyházias) vonásait, az isteni autoritás e két komplementer megnyilatkozását termékeny feszültségben tartva egymással (lásd DULLES 2006 in SZABÓ \& BARTÓK 2006, pp. 173-188)4. Az alapképzés helyszíne az a Maryland állam területén lévő Woodstock College volt, ahol 1960-tól kezdődően maga is tanárként kezd majd müködni. Elöljárói már ekkor olyan tehetségesnek ítélik a fiatal jezsuitát, hogy 1951-ben kétéves időtartamra a New York-i Fordham Egyetemre küldik skolasztikus filozófiát tanítani. Maga Dulles erre az időszakra így tekint vissza:
„Habár életem jelentös részében teológusként tevékenykedtem, tanári pályám 1951 és 1953 közötti szakaszában filozófiatanár voltam a New York-i Fordham Egyetemen. Egyfajta neotomizmust képviseltem a metafizikában és a természetes teológiában, de az ismeretelmélet területén mégis inkább John H. Newman perszonalista látásmódját találtam meggyözöbbnek. Tanulságos volt számomra a felismerés, hogy Newman gondolatvilága sok ponton szorosabban kapcsolódik Arisztotelészhez és Szent Tamáshoz, mint a neotomizmushoz."

(DULLES 2015, p. 165)

Ezen időszakhoz kapcsolódó előadásainak jegyzetanyaga publikált formában is elérhető (DULLES; DEMSKE \& O'CONNELL 1955). ${ }^{5}$

1953-ban teológiai tanulmányainak befejezése céljából Dulles visszatért Woodstockba (lásd CAREY 2010a, pp. 118-133). Itt került kapcsolatba a kor világszerte ismert és elismert jezsuita ökumenistájával, Gustave Weigellel, aki életre szóló hatást gyakorolt Dullesre, ösztönözve őt a hit teológiájában és az egyháztanban való elmélyülésre. Főként Weigel érdeme a protestáns családból származó fiatal teológus ökumenikus érdeklődésének katolikus behangolása. Ezekben az években hasonlóan erős hatást gyakorolt Dullesre John Courtney Murray is, aki a katolikus társadalmi tanítás vonatkozásában mentorálta a fiatal teológust. E társadalmi tanítás egyik eleme az autoritás szerepéről alkotott katolikus felfogás. A modernitás szellemi mátrixában a tekintély kérdésköre olyannyira neuralgikus ponttá lett, hogy akár még a nyugati társadalmak tekintélykomplexusáról is joggal beszélhetünk. Dulles számára

4 A cikk a szerző 1997. április 10-én elhangzott McGinley előadásának szerkesztett átirata.

5 Ennek az időszaknak az életrajzi adatainál Dulles saját visszaemlékezéseire hagyatkozhatunk: DuLLEs 1996a, pp. 95-144. 
már ekkor világossá vált, hogy a keresztény gondolkodásban meg kell haladni a „konformitás vagy szabadság" hamis dilemmáját, illetve az intrinzikus és extrinzikus tekintélyfelfogások dinamikus összekapcsolására, szintézisére kell törekedni. Murray szintén tudós jezsuita volt, aki a II. Vatikáni Zsinaton később a vallásszabadság elvének hatékony képviselőjeként tűnt ki a teológiai szakértők közül. Dulles Weigel és Murray mentori iránymutatása nyomán ismerkedett meg alaposabban a nouvelle théologie legfontosabb képviselőinek (Henri de Lubac SJ, Jean Daniélou SJ, Yves Congar OP) eredményeivel, amely előkészítette őt a II. Vatikáni Zsinat aggiornamentójára. Közülük Congar teológiatörténeti munkássága egy életen át referencia maradt számára, s hasonlóképpen Karl Rahner SJ szisztematizáló ereje és szimbólumközpontú fundamentális teológiája is nagy hatással volt a fiatal jezsuitára (vö. uo. pp. 122, 144, 163, 171, 224; DULLES 1991b, pp. 42-52). Miután 1956-ban pappá szentelték, Dulles a jezsuita képzés újabb szakaszának teljesítésére Münsterbe került (vö. CAREY 2010a, pp. 133-136). Németországi tartózkodása alatt alapos betekintést nyert az európai teológiai diskurzus összetett világába. Az itt szerzett tapasztalatai meghatározó jelentőségünek bizonyultak a fiatal jezsuita doktori témaválasztását illetően (vö. DULLES 1992f, pp. 85-94; 1998b, pp. 28-34).

1958-ban Dulles Rómába került, ahol a Pápai Gergely Egyetemen először rendtársánál, Bernard Lonergannél, majd végül Jan Witténél jelentkezett a doktori témajavaslattal (vö. CAREY 2010a, pp. 144145). 1960-ban védte meg disszertációját, amelyből - a téma gyors fejlődésére tekintettel - csak szemelvényeket publikált (DULLES 1960, pp. 544-580; újraközlés kisebb átdolgozással in DULLES 1961). Dulles doktori disszertációjában a protestáns egyházak Krisztus egyetlen egyházának ,prófétai hivatalában" való részvételét kutatta, amely hivatalt a II. Vatikáni Zsinat előtti katolikus megközelítés csaknem kizárólagosan a Katolikus Egyházhoz rendelte hozzá. Miközben Dulles számításba vette a potestas ordinis és potestas iurisdictionis hiányát a protestáns lelkészek esetében, mégis lehetségesnek látta, hogy a protestáns igehirdetési gyakorlat kegyelemközvetítő és gyümölcsöző hatása mellett érveljen, amennyiben ez a gyakorlat aláveti magát az Ige tekintélyének (authoritas Verbi Divini) és együttmúködik a Szentlélekkel (gratia sermonis), aki hitet ébreszt a hallgatók szívében. A fokozatszerzésen túl Dulles a későbbiekre nézve meghatározó tapasztalatokra tett szert római tartózkodása alatt: szemtanúja lehetett egy egyetemes zsinat összehívásának, lázas előkészületeinek, továbbá a „péteri szolgálat” és a szentszéki dikasztériumok müködésének. Ennek köszönhetően az egyházkormányzat és az autoritás teológiája iránti bontakozó érdeklődése a későbbiekben is hasznosított realitásérzékre tett szert (vö. CAREY 2010a, pp. 137-151).

Családi gyökereinek köszönhetően, valamint a Harvard Law Schoolban megkezdett, a háború miatt félbehagyott jogi tanulmányait követően Avery Dulles alapvető államtudományi ismeretekkel felvértezve fordult az egyházi autoritás témája felé. A fiatal jezsuita, aki XII. Piusz pápa halálakor érkezett Rómába, majd tanúja volt a II. Vatikáni Zsinat összehívásának, illetve 1960-ban a „prófétai hivatalról" írt disszertációja megvédése után visszatért az Egyesült Államokba, érthető érdeklődéssel fordult az egyházkormányzat elméleti kérdései, illetve az autoritás teológiai-egyháztani problematikája felé.

\section{Az első szakmai életszakasz: Woodstock College}

Római doktori tanulmányainak befejeztével Avery Dulles a Maryland állam területén található jezsuita képzési központba kapott diszpozíciót elöljáróitól (lásd uo. pp. 152-180). Abba az intézménybe tért vissza teológiát tanítani, amelynek korábban maga is növendéke volt. 1960 őszén a keresztény kinyilatkoztatás teológiájával, illetve a bibliai sugalmazás elméleteivel foglalkozó, valamint apologetikai tárgyak oktatására kérték fel. Az utóbbi témával kapcsolatos jegyzeteit három év múlva már könyv formájában publikálta (DULLES 1963). Az apologetikát Dulles a hit és értelem dialektikájának tágabb problematikája felöl közelítette meg, hangsúlyozva, hogy bár a bibliai üzenet 
elsősorban hitbeli elköteleződésre hívja az embert, ugyanakkor ez a hívás a teljes embernek szól, akihez korunkban hozzátartozik a tudományos módszer által fémjelzett intellektuális kutatás. A két ismerettípus között megtalált dinamikus egyensúly az amerikai teológus későbbi életművében visszavisszatérő téma marad, ahogyan később ennek jegyében az apologetika egész történetét is feldolgozza (DULLES 1971a).

A kinyilatkoztatás teológiájának folyamatosan elmélyített témája is egy életen át elkíséri Dullest, aki saját maga az e téren kifejtett munkásságát tekinti később a legeredetibb hozzájárulásának a teológiai diskurzushoz (lásd CAREY 2010a, pp. 216-228). Az amerikai teológus kezdettől fogva az Ige teológiája felöl közelíti meg a kinyilatkoztatás fogalmát, amely elsődleges valósághoz csak mintegy másodlagos egyházi realitásként kapcsolódnak a doktrinális állítások (propozíciók). Olyan alapvető szemléletmódról van itt szó, amely a misztérium és a szimbólum bibliai fogalma felöl kiindulva rendszerezi a teológiai episztemológia egyéb elemeit (lásd DULLES 1964a, pp. 43-58; 1969a).

Az 1962-1965 között ülésező II. Vatikáni Zsinat nem csak Avery Dulles teológiai pályafutásának, hanem az egész évszázadnak a legfontosabb egyházi eseménye volt (vö. CAREY 2010a, pp. 211-215; DULLES 1967b, pp. 7-17; 1985d, pp. 3-10; 1986a). Hazatérését követően az amerikai teológus távolból követte és honfitársai számára szakavatottan közvetítette kora egyetemes zsinatának iránymutatásait, majd a zsinati döntések megvalósításában maga is tevékenyen részt vállalt (lásd pl. DULLES 1966, pp. 217-231). Dulles szakmai elismertségét jelzi, hogy 1965-ben a zsinati dokumentumok standard angol nyelvü kiadásának szerkesztőitől felkérést kapott, hogy írjon szakkommentárt a Lumen Gentiumhoz, és lássa el azt magyarázó lábjegyzetekkel (АВBOTT 1966). ${ }^{6}$ E munka végeztével örömmel nyugtázta, hogy saját érdeklődésének a kinyilatkoztatás teológiájához és egyháztanhoz kapcsolódó fő irányai egybevágnak a zsinati munka alapvető irányaival. Az ekkor negyvenes éveiben járó jezsuita a zsinat recepciójával összefüggésben, a korabeli szélsőségeket érzékelve, a folytonosság és reform egészséges egyensúlyát kereste. ${ }^{7}$

Dulles magisztérium-elmélet elmélyítésére irányuló egész pályáját végig kíséri a II. Vatikáni Zsinattól nyert inspiráció. Az amerikai teológus müveiben beazonosíthatunk hét karakteresen zsinati ihletettségü belátást, amelyek a szerző autoritás-felfogásának fundamentális teológiai pilléreit jelentik. Azt is látnunk kell, hogy az elméleti kutatásokon keresztül Dulles ezúttal is gyakorlatias: a tekintélygyakorlás terén bekövetkezett zsinat utáni elbizonytalanodásra keresett megoldást. A cikkben vizsgált téma kifejtését meghatározó, Dulles által számon tartott hét zsinati alapelvet e ponton részletesebben is érdemes összefoglalnunk:

1) Dulles szerint a tanítóhivatal neoskolasztikus felfogása nem tükrözi megfelelően a Szentírás és a Hagyomány normatív tanúbizonyságát, ezért a magisztérium megújult tárgyalásának a biblikuspatrisztikus alapozásra gondosabb figyelmet kell fordítania.

Az idők során az Újszövetség „tekintély” (exusia) fogalmának számtalan árnyalata elveszett a neoskolasztikus teológiai tárgyalás számára, ami egy erősen jogi szemléletü, piramidális egyháztan kialakulásához vezetett. ${ }^{8}$ A modern szentírástudomány szerint a legtöbb esetben egzegetikailag megalapozatlanok azok az apologetikus célú bibliai hivatkozások, amelyekkel az egyoldalúan

6 A kommentárokon keresztül érdekes megfigyelni, hogy a zsinat utolsó éveiben, majd azt követően, a magisztérium teológiáját szorosabban érintő kérdésekben Dulles csak fokozatosan értékeli át az általa korábban tanult manualisztikus autoritás-teológiát, amelyet ettől kezdve igyekszik a zsinati egyháztan követelményeihez igazítani (vö. JANKIEWICZ 2009, p. 110).

7 A szerző első pályaszakaszra jellemző beállítottságát jól dokumentálja az a szövegrész, amely minden bizonnyal a legkorábbi magyarra fordított tőle származó szöveg (DuLLEs 1968c, pp. 49-51).

8 Dulles észrevételezi, hogy modern fordításokon keresztül találkozva ezekkel a szöveghelyekkel félrevezető lehet, hogy az esetek kétharmadában olyankor is ,hatalom” értelemben fordítják az exusia szót, amikor ez teológiai szempontból nem indokolt. Hozzátehetjük, hogy a jezsuita szerzőnek ez a megállapítása a szélesebb körben használt magyar fordítások szempontjából is megállja a helyét. 
„monarchikus jellegü” barokk egyháztan igazolni kívánta a maga intézményrendszerének újszövetségi eredetét. Nincs elegendő szentírási adat ahhoz, hogy már az első keresztény generáció egyházi életében kimutatható legyen egy, a neoskolasztikus teológia szemléletmódja szerinti magisztérium működése.

Dulles a tanítványság biblikus paradigmájából kiindulva vázolja fel a pluralisztikus tekintélyelmélet és az ennek megfelelő autoritás-felfogás fontosabb mozzanatait. Már az apostoli hagyományrétegben rámutat a kommunió és a hierarchia ősi dialektikájára, a különböző vezetői szerepek párhuzamos jelenlétére, az intézmény és karizma egymást támogató kapcsolatára, a konszenzus jelentőségére, valamint a hit és a hagyományozás eredendő „recepciós szerkezetére”. Az újszövetségi egyházkép és annak patrisztikus recepciója szervesebb, markánsan közösségibb, karizmatikusabb a neoskolasztikus megfelelőjénél, amire a II. Vatikáni Zsinat fel is hívta a figyelmet.

2) Dulles szerint a tanítóhivatal neoskolasztikus tárgyalása nem vet számot kellőképpen a teológiatörténet sokrétủ adataival, valamint a késő modern ember történelmi tudatosságával: ilyen vonatkozásban is aktualizálásra szorul.

Dulles megítélése szerint a neoskolasztika intézményi időtlenséget és tévedhetetlenséget középpontba állító magisztérium-felfogása - paradox módon - sok fontos vonásában csak a 19. században alakult ki. Ez az antimodernizmus hatására megcsontosodó szemléletmód a történeti fejlódés elfogadásában sokszor csupán a doktrinális relativizmus veszélyét látta, amelynek érthető módon minden erejével ellene szegült. Ugyanakkor a történeti tudat modern emberre jellemző felerősödése nyomán az egyház történeti naivitással jellemezhető szubkultúrája problémává vált.

A II. Vatikáni Zsinat krisztocentrikus és üdvtörténeti látásmódja a magisztérium teológiájára is hatással volt. Dulles üdvözli a történetiséghez füződő pozitívabb viszonyulást, amely számot vet azzal, hogy a modern ember sokszor joggal bizalmatlan az igazság ,abszolutisztikus” megközelítései, a naiv realizmus és az azzal társuló történetietlen doktrinális szemlélet irányában. A jezsuita teológus a klasszikus analógiatanra alapozott „szimbolikus realizmus” útján és a „szituácionalista tanfejlődés” modelljét alkalmazva próbálja kikerülni a történeti relativizmus és a theologia perennis problémás szélsőségeit. Dulles meg van győződve arról, hogy a magisztérium intézménye konstitutív eleme az egyház életének, ugyanakkor - történeti adatok alapján - fontosnak tartja hangsúlyozni, hogy az egyház életét szabályozó autoritás-konfigurációk koronként más-más hangoltságúak lehetnek. A magisztérium szerepének ez az egyház üdvtörténeti missziójához alkalmazkodó rugalmassága maga is az isteni terv részének tekinthető.

3) Dulles szerint a tanítóhivatal neoskolasztikus teológiáját a kommunió-egyháztan kontextusába illesztve lehet (és szükséges is) elmélyíteni, a „hivatalt” az egyház egészével fennálló kölcsönviszonyban értelmezve.

A barokk teológiából eredeztethető éles különbségtétel, amely episztemológiai és kegyelemtani szempontból egyaránt ecclesia docensre és ecclesia discensre választotta szét az egyetlen egyházi kommuniót, a tanítói autoritásnak egy erősen beszükült teológiáját eredményezte. Dulles szerint a neoskolasztikus szerzők többségét olvasva már-már az lehetett az ember benyomása, hogy a klérus az elsődlegesen neki címzett kinyilatkoztatásnál, a teológiai képzettségénél, valamint az életállapotának tulajdonított erényeknél fogva úgy birtokolja az igazságot, ahogy senki más az egyházban. A laikus hívők hivatása ezzel szemben egyszerüen a klérus által autoriter módon közvetített igazság passzív befogadására korlátozódik. Dulles szerint ez az egyházat polarizáló, piramidális egyházkép a másodlagos autoritás-szerkezet torz konfigurációját veszi alapul. A jezsuita teológus szerint az egyházi tanítás erejét és hitelességét veszti, ha az nem az egész hívő közösség hitvallásaként ölt formát.

Dulles a hagyomány mélyebb rétegeihez való visszatérést látja a II. Vatikáni Zsinat azon irányvételében, hogy a tanítóhivatalt a hitletéteményt tanúsító Szentírással és Apostoli Hagyománnyal szerves egységben, illetve a hívők hitérzékével és az akadémiai teológiával dinamikus kapcsolatban próbálták visszavezetni saját identitásának gyökereihez. A jezsuita teológus szerint a zsinat által 
körvonalazott - bár meg nem nevezett - kommunió-egyháztan olyan egészséges értelmezési keretet kínál a megújuló magisztériumteológia számára, amelynek még távolról sem lettek kiaknázva a lehetőségei. Dulles a saját pluralisztikus tekintélyelméletét ennek a megújulási törekvésnek a vonalában helyezi el.

4) Dulles szerint a tévedhetetlenség (infallibilitas) ünnepélyes tanítóhivatali aktusokban müködő sajátos karizmáját az egész egyház hitbeli tévedhetetlenségének általános kontextusában, pneumatológiai horizonton lehet érthetővé tenni.

Dulles hangsúlyozza, hogy a neoskolasztikus egyháztan a „doktrinális extrinzikizmus” hibájába esett, amely magával hozta a vakon vállalt beleegyezés (,,blank check” theory of assent) értelmében felfogott passzív engedelmesség követelményének hangsúlyozását, illetve a tanítói tekintély hitelességének csaknem mágikus szemléletmódját. A gyengén kidolgozott pneumatológia nem ösztönözte Isten és ember együttmúködésében a kor igényeinek megfelelö, differenciált leírást, amely pedig szükséges lett volna a szekularizációs áramlatokat fékező párbeszéd légkörének megteremtéséhez. A pápai primátus maximalista értelmezése a katolikus egyház szervezeti kultúrájában megteremtette a kvázi-fideizmus légkörét, amely a tekintély hordozónak a közösségben kialakított szerepét előnytelenül formálta.

A II. Vatikáni Zsinat utat nyit egy olyan többpólusú tekintélyteológia irányába, amely a tévedhetetlenség ajándékát Isten hüségének összefüggésében, a népével kötött szövetség kategóriái szerint értelmezi. E teológiai szemléletben természetes, hogy Isten Igéjének a befogadása (recepciója) gyakorta az emberi bölcsesség és tudomány elemeivel keveredik az egyház hittudatában. Ugyanakkor az egész egyház - mint a kinyilatkoztatás címzettje - teljes bizonyossággal, tévedhetetlen tekintéllyel képes a hittudat magvát jelentő hitletétemény megragadasára. Ezt a tévedhetetlen egyházat képviseli de facto és de iure a püspöki kollégium a pápa fösége alatt, amikor korporatív módon - az utóbbi két vatikáni zsinat által leírt formációkban - ünnepélyesen is kiállnak az egyház hitéért. Dulles szerint ennek a kollegiális dimenziónak a kiemelése a II. Vatikáni Zsinat legfontosabb hozzájárulása az infallibilitas teológiájának elmélyítéséhez.

5) Dulles meggyőződése, hogy a hivatali tekintély sajátos, integratív módon közvetíti Krisztus elsődleges tanítói autoritását, ám ettől világosan megkülönböztetve - ha nem is elszigetelve beszélhetünk az egyházzal közösségben lévő teológusi testület akadémiai tekintélyéről, más természetü „magisztériumáról” is, amely az egyház életfunkciójaként kapcsolódik az előbbihez.

A neoskolasztika Dulles által „szeparatistaként” leírt megközelítésmódjában a hierarchia magisztériuma teljességgel elkülönült a „teológusok magisztériumától”, lévén hogy az előbbit tekintették a kinyilatkoztatás címzettjének, az Apostoli Hagyomány átörökítőjének, a Szentlélektől kapott hivatali karizma birtokosának, bizonyos kvázi többlettudás beavatottjának. Ennek függvényében a teológusoknak csak delegált tekintélyt tulajdonítottak, amikor segítő szervként (auxiliary organ) igénybe vették a szolgálataikat, szaktudásukat. E szemléletmódban a tanítói autoritás monopóliuma a püspökök birtokában volt.

A II. Vatikáni Zsinat által képviselt teológiai paradigmaváltás jelentős mértékben kiegyensúlyozta a korábbi évszázadra jellemző gondolkodási minta egyoldalúságait. Dulles „dialektikus” megközelítésmódja szintén világosan megkülönbözteti egymástól a két csoportot, miközben az egymásra utaltságuk is hangsúlyt kap. Mindkét autoritás-forma (a hivatali és az akadémikus tekintély) egyaránt konstitutív eleme az egyház életének, és még a megfelelő keretek között tartott feszültségük is lehet építő jellegü az egyház küldetése szempontjából. Dulles világosan rámutat arra, hogy a szimbolikus közvetítés és a tanítványság összekapcsolódó paradigmájában ki lehet küszöbölni a kinyilatkoztatás és egyházmodellek azon egyoldalú használatát, amely a neoskolasztikus szemléletmód problémáihoz vezetett. A püspökök és teológusok dialektikusan felfogott kapcsolata, és az ennek 
megfelelő aszimmetrikus tanítói tekintélyek végeredményben Dulles tágabb látószögü pluralisztikus autoritásteológiájának egy alrendszerét jelentik.

6) Bár a neoskolasztikus időszakban az egyházi tekintélygyakorlást a teológiai diskurzus mesterséges uniformizálásának szándéka jellemezte, egy bizonyos térben és időben jelentkező katolikus pluralitás - Dulles meggyőződése szerint - az egyházi élet szerves része, amely nem sérti a hitbeli egységet.

A szekularizmus 19. századi támadásaival szemben a katolikus egyházi élet meghatározó köreiben kialakult az a meggyőződés, hogy az „összezáráshoz” szükséges szervezeti egységet csak a szigorú doktrinális egység biztosíthatja, amely uniformitásnak pedig csak egy biztonságot adó centrális erőtér lehet a garanciája. Ez az egyházpolitikai szempontból érthető tendencia a teológiai diskurzus - az egész egyháztörténet léptékében példátlan mértékü - uniformizálódásához vezetett. Dulles megítélése szerint az extrinzikus autoritás ilyen előtérbe kerülése elsorvasztotta a katolikus teológiai pluralitásban rejlő intrinzikus tekintély evangelizációs eröit.

A II. Vatikáni Zsinattól merített ösztönzés nyomán a jezsuita teológus következetesen kiállt az egyházban müködő autoritás-struktúra pluralisztikus, többpólusú szemléletmódja mellett. Dulles felfogása szerint az egyház hitbeli egysége nem azonosítható az uniformizált doktrinális egységgel, hiszen a hit maga sem azonosítható az arra reflektáló teológiával. Az egyház evangelizációs erejének visszanyeréséhez kifejezetten kívánatos lehet, hogy különböző teológiai elképzelések kiegészítsék és korrigálják egymást, magasabb szinten mutatva rá a szintézis lehetőségére. A jezsuita szerző e szemléletmódja jegyében dolgozta ki és alkalmazta több területen is a modellanalízis sajátos módszerét.

7) Az egyház új evangelizációs küldetésével összefüggésben, a tanítói tekintély gyakorlása terén evangéliumi szellemben megújult stílusra van szükség, amelyhez - Dulles szerint - egy hiteles autoritásteológia teremtheti meg az alapot.

Dulles a neoskolasztikus időszakban felgyorsult szekularizációs folyamat egyik összetevőjét az egyház szervezeti kultúrájának az evangéliumi gyökerektől elidegenedett, autoriter tekintélygyakorlási stílusában, bürokratizmusában, szük látókörü merevségében vélte beazonosítani. A másodlagos tekintélyi struktúra ilyen módon nem tudta kellő transzparenciával és hatékonyan közvetíteni Krisztus par excellence autoritását.

A jezsuita teológus meggyőződése szerint a tanítói autoritás természetéről és a tanítói gyakorlatról alkotott képünket szüntelen közelítenünk kell az Evangéliumhoz, és a krisztusi tanítványság paradigmájának összefüggésében kell újragondolnunk. Ha a hierarchikus tekintély hordozója és az egyház többi tagja egyaránt az egyetlen Mesterre tekint, az szolgálatra hangolja a tanító stílusát és befogadóvá teszi a tanítványt. Szójátékkal kifejezve: nyilvánvalóvá válik a magisztérium minisztérium jellege. A II. Vatikáni Zsinat autoritás-teológiája az egyház szervezeti kultúrájában szorgalmazza az elmozdulást a túlzottan autokratikus és centralizált tanítóhivatali gyakorlattól egy kollegiálisabb és karakterében konzultatívabb gyakorlat felé.

Dulles az általa kidolgozott magisztérium-teológia egyháztani kontextusát „a szakrális autoritás pluralisztikus elméleteként" írta le, amely elmélet kidolgozását a II. Vatikáni Zsinat kommunióegyháztanának tágabb keretében vitte végig: egyfelől tekintettel arra a kommunióra, amely Krisztus és egyháza között áll fenn, másfelől tekintettel arra a kommunióra, amely Róma püspöke és a püspöki kollégium, illetve a püspökökhöz tartozó helyi egyházak között valósul meg. E két alapvető teológiai dimenziónak megfelelően Dulles megkülönbözteti az első esetben a megtestesült Logosz (Krisztus) par excellence isteni autoritását, amelyet az egyház tekintélyi struktúrája közvetíteni hivatott, illetve a második esetben az egyházban megtalálható „másodlagos tekintélyhordozókat”, amelyeknek lényeges jellemzője a strukturált sokféleség, és amelyek különböző korokban kissé eltérő alakzatokba, konfigurációkba szerveződtek. A másodlagos tekintélyhordozók között Dulles a Szentírást, a Szenthagyományt, a hívők hitérzékét, a hierarchia magisztériumát vagy lelkipásztori hivatalt („hivatali 
autoritás”) és a teológusok testületét (,,akadémikus autoritás”) nevezi meg. A jezsuita szerző elmélete szerint ezek az egymással sokrétü, dinamikus kapcsolatban álló autoritás-intézmények Isten bölcs elgondolása szerint olyan egységbe szerveződnek, amelyben egyik sem töltheti be a maga egyházi funkcióját a másik négy hozzájárulása nélkül, miközben mindegyik intézmény a maga sajátos módján illeszkedik az egyház életébe. Az autoritás rendszeres (szisztematikus) teológiája megvilágítja, hogy Krisztus - mint elsődleges, isteni autoritás, aki minden másodlagos autoritás forrása - miképpen kíséri és vezeti zarándok népét az üdvösségtörténetben. Az autoritás helyesen felfogott teológiája így valójában az egyháztan gerince, a kánonjog alapvetése.

Dulles az 1967-ben publikált első egyháztani könyvében (The Dimensions of the Church) olyan üdvtörténeti valóságként vizsgálta az egyházat, amely mind a hagyománnyal ápolt folytonosságnak, mind az egyetemes emberi család szolgálatára való nyitottságnak a letéteményese (DULLES 1967a). Ebben a tanulmányban és Dulles ekkoriban publikált ökumenikus tanulmánykötetében (DULLES 1968a) még embrionális formában ugyan, de már felbukkan az egyházkormányzat teológiájának a témája is, amely kérdéskör a szerzőt ettől kezdve élete végéig egyre intenzívebben foglalkoztatta (vö. CAREY 2010a, pp. 232-237; DULLES 1968d, pp. 52-62; 1969b, pp. 299-311; 1970b pp. 29-45). A II. Vatikáni Zsinattól - amely maga is tanítóhivatali esemény - inspirálva, a jezsuita teológus megpróbálta összeegyeztetni egyfelől a különböző tekintélyi rangsorolású doktrinális állítások történelmi beágyazottságát, másfelől a zarándokegyház által közvetített misztérium eszkatologikus érvényét. Dulles téma iránti intenzív érdeklödését jelzi, hogy már 1971-ben The Survival of Dogma címen egy kötetbe szerkesztve is publikálta az ilyen irányú folyóiratcikkeit (DULLES 1971b; vö. CAREY 2010a, pp. 224-229).

Az amerikai teológus pályája kezdetétől fogva hangsúlyozta, hogy a zsinat után különösen is szükség van arra, hogy az egyház szervezeti kultúrája a korábbinál differenciáltabban közelítse meg a hivatali tekintély („hierarchikus autoritás”) közösségi szolgálatát. Az átszármazott, ma már sokszor koridegen módon elnagyolt kategóriák nem töltik be az eredetileg nekik szánt szerepet. Barokk örökség, hogy tekintélyi intézményeink doktrinális tanúságtételét mind a hivatali karizmák (különleges és általános asszisztencia), mind a résztvevő tanítóhivatali szervek vonatkozásában, illetve a megnyilatkozások érvényességi tartománya (hit és erkölcs) vagy formái (definitív vagy nem definitív) felöl egyaránt nehezünkre esik kellően árnyaltan szemlélni. Akár a tanfejlődés teológiai kontextusában, akár a „posztkonciliáris szindróma" lelkipásztori összefüggésében sürgető a differenciáltabb megközelítés: szükség van a „müködés” pontosabb teológiai leírására, illetve az arányosan önkorlátozó tanítói gyakorlat felé tartó stílusváltásra.

Az életút e pontján még csak az 1971-ben publikált könyv (The Survival of Dogma) fókuszált ismertetésének keretei között mutatjuk be Dulles „teremtetlen” és „teremtett” tekintélyek rendszerére vonatkozó alapvető elgondolását. A jezsuita gondolkodó többpólusú, de összességében az egyetlen megtestesült Igére (Krisztusra) mutató autoritás-felfogásának az első szabatos előterjesztése ebben a kötetben található, bár a koncepció még nem kap olyan karakteres elnevezést, mint a későbbiekben (lásd DULLES 1971b, pp. 79-94). Dulles tekintélyelméleti alapgondolata azonban már itt is határozott alakot ölt. A szerző koncepciója szerint különbséget kell tenni az „elsődleges (isteni) autoritás” és a „másodlagos (egyházi) autoritások” között, amelyek „konvergenciája” azonban a hiteles egyházi tekintélystruktúrában spontán módon megvalósul. Dulles leszögezi, hogy a kereszténység - mint a megtestesült Logosz kultusza - lényegéből fakadóan ,tekintélyalapú vallás” (uo. p. 82; vö. DULLES 2002b, pp. 15-26). A másodlagos tekintélyeket illetően pedig hozzáteszi:

„A kereszténység a maga sajátos szellemiségét jórészt autoritás-intézményei gondosan kiegyensúlyozott rendszerének köszönheti." (DULLES 1971b, pp. 84)

A szerző mindezt diakrón és szinkrón összefüggésben is elhelyezi. Egyrészt a „tekintély-helyek” (loci of authority) szóhasználattal ahhoz az elmélethez kapcsolja a magáét, amelyet Melchior Cano állított fel 
a 16. században a teológiai rátalálási helyekröl. Másrészt Dulles többszörös utalásokat tesz az autoritás velünk élö „differenciálatlan” paternalisztikus modelljeire, amelyekkel szemben - szerinte - a II. Vatikáni Zsinat új, pluralisztikus szemléletmódot követ. Ez utóbbi érve legmarkánsabban a kinyilatkoztatásról szóló dogmatikus konstitúció következő kijelentésével támasztható alá:

„Világos tehát, hogy Isten bölcs rendelkezése szerint annyira összetartozik és egymásra van utalva a Szent Hagyomány, a Szentírás és az Egyházi Tanitóhivatal, hogy egyikük sem lehet meg a másik kettö nélkül. Mind a három együttesen, de mindegyikük a saját módján, az egy Szentlélek tevékenységének hatására eredményesen szolgálja a lelkek üdvösségét." (DV 10)

Ahogyan a II. Vatikáni Zsinat néhány mondattal korábban azt is megállapítja, hogy „a Tanitóhivatal nem Isten szava fölött, hanem annak szolgálatában áll " (DV 10), úgy Dulles is ragaszkodik ahhoz, hogy a legfelsőbb és végső tekintély csakis Krisztust illeti, és a magisztériumnak is valójában mint „minisztériumnak” (szolgáló szervként) határozható meg az üdvtörténeti helye (vö. DULLES 2007, p. 101).

A másodlagos tekintélyek különbözö történelmi korokban kissé eltérően behangolt rendszerének a küldetése nem más, mint a Krisztus-esemény közvetítése (vö. DULLES 1971b, pp. 85-86). Ahogy a bevezetésben már említettük, az 1971-es kötetben Dulles ezeket az egymással kölcsönös kapcsolatban álló és egymást kiegyensúlyozó másodlagos tekintélyeket - amint már utaltunk rá - a következőképpen sorolja fel: Szentírás, Hagyomány, a hívők testületének hitérzéke, hivatali tekintély (hierarchikus autoritás), teológusok (akadémikus autoritás). A nagy szentek, illetve az egyházatyák és egyháztanítók tanúságtétele az utóbbi három tekintélyformából egyaránt tartalmazhat keveredỏ elemeket. A jezsuita teológus azt hangsúlyozza, hogy mivel egyetlen „elsődleges” tekintélyhez rendelődik hozzá minden „másodlagos” tekintély, azért ezen utóbbiak egyike sem abszolutizálható (vö. uo. pp. 84-85). Dulles felfogása szerint, ha ilyen abszolutizálódási tendencia bekövetkeznék, melynek során az egyik szereplő a többi kárára kerül a középpontba, az gyengíti az egész rendszer közvetítői szolgálatát (vö. uo. p. 85). Dulles tehát itt is egyensúlyt keres a keresztény értékek védelmében szükséges ellenálláshoz nélkülözhetetlennek tünő, de a karizmákat háttérbe szorító „erős autoritás”, valamint az egyház szervezeti kultúráját irányítani képtelen „gyenge autoritás” szélsőségei között. A jezsuita teológus által folyamatosan fejlesztett, illetve újraértékelt elmélet tárgyalására még többszörösen vissza kell térnünk az egyes életszakaszoknak megfelelően, illetve a szerző kinyilatkoztatás-teológiájával és egyháztanával összefüggésben.

Miközben Dulles az autoritás teológiájának elméleti tanulmányozásában lépésről lépésre haladt elöre, olyan egyházi bizottságokba kapott szakértői felkéréseket, amelyek egyetemes és helyi szinten is fokozatosan bekapcsolták öt a püspökök pásztori szolgálatának gyakorlatába, ilyen módon visszacsatolva az elméletet a gyakorlathoz és viszont. 1966-tól például a jezsuita fundamentálteológus hét évre a római székhelyü, nemhívőkkel folytatott párbeszéd előmozdítására alapított pápai titkárság konzultora lett, míg 1969-től az amerikai püspöki kar tanácsadójaként szolgált (vö. CAREY 2010a, pp. 249, 257; lásd még Dulles 1968b, pp. 17-28; 1973b pp. 71-80). A különbözö ökumenikus szakbizottságokban való részvétel kontextualizálta Dulles gondolkodásában az alapvető teológiai kérdéseket (lásd DULLES 1972, pp. 199-234; 1973a, pp. 643-678; 1971c, pp. 6-16; 1974a; 1996c, pp. 28-37). Hasonlóan összetett - egyházi autoritással kapcsolatos - elméleti és gyakorlati tapasztalatokat hozott Dulles számára a Humanae Vitae enciklika (1968) nemzetközi és amerikai recepciós krízise, valamint a Hans Küng körül kialakult, a tévedhetetlenség egyháztani kérdéseiről szóló vita (vö. CAREY 2010a, pp. 238-240, 242-246). Ezek a sokszor elmérgesedő teológiai viták, amelyekben Dulles a rá jellemző higgadt megfontoltsággal igyekezett részt venni, e pályaszakasz utolsó éveiben jellegzetes ösztönzői voltak az egyházi tekintélyről szóló reflexióinak. 
Dulles a többi akadémiai tudományág mintájára és interdiszciplináris érzékenységgel gondolkodott a teológiáról (vö. DULLES 1970a, pp. 485-502). Szemléletmódjának kialakulásához jelentősen hozzájárult a magyar származású Michael Polányi (1891-1976), aki kiváló elméleti vegyészként és társadalomtudósként egyaránt érdeklődéssel fordult a tudományelméleti kérdések felé (vö. CAREY 2010a, pp. 219-220, 226, 312-316, 345, 384, 387, 407, 411, 483). Az amerikai jezsuita számára Polányi életmüve alkalmat adott a tudományos felfedezések, az akadémiai közösségek múködése, a kutatási módszertan és a krisztusi tanítványság bizonyos vonásainak az összevetésére (lásd DULLES 1984a, pp. 537-550). ${ }^{9}$ Polányi természetesen nem foglalkozott részletesen az egyház tanítói tekintélyének kérdéseivel, Dulles azonban inspirációt merített Polányitól a teológia mint tudományos vállalkozás reflexiójához, a tanfejlődés átgondolásához, a modellanalízis módszerének kidolgozásához. Dulles számára megvilágosító erejü volt a civil, polihisztor tudósnak az akadémiai közösségben való részvétel és a tudományos vállalkozás művelésének lényegi kapcsolatáról szóló gondolatmenete, amelyet a fundamentálteológus jól alkalmazhatónak vélt a krisztusi tanítványság egyházias jellegének leírására (lásd POLÁNYI $1964^{10}$, pp. 53-54, 207-209; vö. DULLES 1984a, p. 541). Polányi nyomán kialakított meggyőződése szerint - és ezt későbbi pályaszakaszában Dulles részletesebben is kifejtette - az isteni önközlést közvetítő szimbólumokhoz való kapcsolódás által a hívők egyrészt istentapasztalatra tesznek szert, másrészt szocializálódnak abban a közösségben, amely a keresztény identitás letéteményese (vö. DULLES $1995^{2}$ a, pp. 18-20, 24, 26, 28, 34-38, 65-66; 1988a, pp. 85, 86, 88; 1984a, p. 541). A Polányival folytatott dialógusban Dulles beazonosítja és rendszerelméletileg elemzi a vallási közösség, az elköteleződés, a hierarchikus vezetés, a kánoni normák, a hagyomány egyházi jelenségeinek szekuláris analógiáit (vö. DULLES 1991a in FIORENZA \& GALVIN 1991, p. 121; SHECTERLE1996, pp. 180-186). A jezsuita teológus itt röviden összefoglalt „interdiszciplináris kalandja” később harmonikusan asszimilálódott a szerző katolikus gondolatvilágába, és a következő pályaszakaszban a modellanalízisként ismertté váló gondolkodási stílusának szerves részévé vált.

A Biblia, amikor valamilyen konkrét teológiai témát próbál megvilágítani, szinte kizárólag csak képekben beszél, fóként metaforikus képekben. A vallás világában a képek szimbólumokként müködnek, vagyis egzisztenciálisan szólnak az emberhez, tagolatlanul beágyazódnak tudatának mélyrétegeibe, hogy ott fejtsék ki hatásukat. Maga a teológia is nagymértékben függ a képektöl. Az akadémiai diskurzus számára azonban az elemzés nélkül hagyott képnek nagyon korlátozott az értéke. Amikor a teológus képeket használ, azért teszi, hogy elmélyültebben érthesse meg a hit titkait. Tudja, hogy a képek korlátozott módon hasznosak, de a korlátokat szem elől tévesztve félrevezetőek is lehetnek. Amikor egy képet értelmezési eszközként reflektív módon, de ugyanakkor kritikai tudatossággal használnak fel, mai szóhasználattal „modellé” válik.

A modellnek a Dulles által kiaknázott fogalma otthonosabb a modern természettudományok gondolkodási kultúrájában, mint a teológiában (vö. CAREY 2010a, pp. 211-273). Ugyanakkor az, amiről itt szó van, gyakorlatilag a keresztény teológiában nagy hagyományokkal rendelkező analógiatan megfelelöje. Gyökérmetaforáink erőterében szimbólumrendszereink „modellekké” kristályosodnak, mert a teológiai ábrázolások csak távolról közelítik a tárgyat, amelyet vizsgálnak: még sokkal távolabbról, mint a szekuláris tudomány reprezentációi.

A modellek használata a teológiában részben magyarázó, részben heurisztikus szerepet tölt be. Magyarázó szinten a modellek arra szolgálhatnak, hogy szintetizálják azt, amit már tudunk. A modell akkor fogadható el, ha nagyszámú bibliai és hagyományos adat támasztja alá, és összhangban van azzal, amit a történelem és a tapasztalat mond a keresztény életről. Mivel a teológiai témák az elkötelezett keresztények szívében élnek, olyan valóságként, amelyben ők egész életükkel részesednek, ezért saját tapasztalatukból kiindulva állapíthatják meg a különböző modellek helyességét és határait. A modellek

Dulles e cikkében maga reflektál arra, hogy miképpen hatottak teológiai gondolkodására Polányi eszméi.

A mü magyarul is megjelent: POLÁNYI 1994. 
feltáró vagy heurisztikus használatán azt a képességüket értjük, hogy új teológiai meglátásokhoz vezethetnek. A fentiek után természetesnek tünik, hogy egy konkrét teológiai téma feldolgozásakor elkerülhetetlen a modellek pluralizmusa. Ez a pluralizmus nem logikai zavart tükröz, hanem teológiai életerőt. Az, hogy minden modellnek vannak gyenge pontjai és egyik sem tehető kizárólagossá mint az összes többinek a mértéke, arra mutat rá, hogy a keresztény misztérium nem hozható tökéletes párhuzamba tapasztalati világunk egyetlen objektumával sem. Ráadásul a teológiai témákat egyfajta hitünkben gyökerezö, kölcsönös szubjektivitás által ismerjük a maguk objektív valóságában. Mindazonáltal a hiteles teológia - a modellek e pluralizmusába beletörődve - általában megpróbálja a pluralizmust a minimálisra csökkenteni, hiszen a magyarázatot kereső emberi értelem a megismerés koherenciájára törekszik. Bár az egyház történetében nemegyszer lehetségesnek vélték a totális teológia megalkotását, egy-egy témában egyetlen modellre alapozva, valójában azonban ez a - Dulles számára olyannyira fontos - misztériumközpontú szemlélet kárára lenne.

\section{A második szakmai életszakasz: The Catholic University of America}

Avery Dulles második pályaszakasza (1974-1988) akadémiai élete kivirágzását hozta (lásd CAREY 2010a, pp. 306-348). Miközben különböző szentszéki és amerikai püspöki testületek alkalmi tanácsadójaként további tapasztalatokat szerzett a hivatali tekintély („hierarchia magisztériuma”, „lelkipásztori hivatal”) egyházi szolgálatáról, az egyházi autoritás teológiája publikációinak folyamatos témája maradt (lásd DULLES 1985b, pp 528-534). Dulles ökumenikus tevékenysége, felekezetközi teológiai bizottságokban való részvétele is intenzívebb lett ebben az időszakban, s ez az aktivitás sokszor a sajátosan katolikus témák feldolgozását kontextualizálta (lásd DULLES 1991d, pp. 32-44). Az amerikai teológus jelen cikkben vizsgált gondolati fejlődése szempontjából e pályaszakasz legfontosabb mérföldköveit két újabb kötet központi tanulmányai jelentik (The Resilient Church, 1978; A Church to Believe In, 1982), amelyeket fö témánkra fókuszáltan részletesebben is bemutatunk. Dulles neve ugyanakkor ebben az időszakban a modellanalízis módszerének kidolgozásával összefüggésben vált nemzetközileg ismertté. 1974-ben jelentette meg a Models of the Church (DULLES 1974b; majd újabb, kibővített kiadásban 1987a; magyarul 2003a) címü, azóta féltucatnyi nyelvre lefordított könyvét, amelyet 1983-ban a Models of Revelation (DULLES 1983a; magyarul 2005a) követett. E munkáiban a kinyilatkoztató Isten elsődleges autoritásának, illetve az ezt közvetítő másodlagos egyházi autoritások kapcsolatrendszerének szentel figyelmet, miközben fundamentális teológiai horizonton járja körül az alaptémát.

Az Amerikai Katolikus Püspöki Konferencia (USCCB) által alapított és fenntartott Amerikai Katolikus Egyetem (Washington, DC), ahol ebben az időszakban Dulles oktatott és kutatott, az ország katolikus intellektuális életének az egyik központja (vö. CAREY 2010a, p. 272). A woodstocki jezsuita képzési központ megszünése után Dulles ide kapott professzori felkérést fundamentális teológiai tárgyak oktatására. Az amerikai teológus ekkor már országos és nemzetközi szinten is jegyzett „középutas” szerző volt, aki 1975-1976 között az Amerikai Katolikus Teológiai Társaság (CTSA), valamint 19781979 között az Amerikai Teológiai Társaság (ATS) elnöki tisztségét töltötte be (vö. DULLES 1996a, pp. 120-121; 1975, pp. 334-337; 1976e in BERGER \& NEUHAUS 1976, pp. 44-62; DULLES 1980e, pp. $155-$ 169). Ezen túlmenően ebben az időszakban Dulles vendégprofesszori meghívásokat kapott - többek között - a Pápai Gergely Egyetemtől (Róma), a Union Theological Seminarytól (New York), a Princeton Theological Seminarytól (Princeton), a Boston College-tól (Cambridge, MA), valamint az Oxfordi Egyetemtől (Egyesült Királyság). Oxfordi vendégprofesszori látogatása során Dulles különösen is kidolgozta egyháztanának az isteni misztériumra irányuló, szakramentális teológiai mozzanatait (lásd DULLES 1982b in LATOURELLE \& O'COLLINS1982, pp. 259-273). Ez az egyháztan paradox módon számol egyrészt az egyház intézményi valóságával, másrészt egy olyan katolikus értelemben vett 
„anonim egyházzal”, amely krisztocentrikus, de a kötődés szempontjából koncentrikus rétegzettségü, strukturált közösség. Ide kapcsolódó - nyilvánvalóan ökumenikus ihletettségü - gondolatait Dulles The Catholicity of the Church címen könyv formájában is közreadta (DULLES 1985a).

Mivel e tanulmány az autoritás teológiájára fókuszáltan elemzi Dulles gondolati fejlődését, ezért fontos kitérnünk a szerző egyháztani, valamint episztemológiai irányú munkásságára is, amely két reflexiós terület segít tágabb összefüggésben is elhelyezni a központi témát. A legfontosabb, második pályaszakaszhoz tartozó, az autoritás teológiájának kidolgozását keretező eredmények a modellanalízis módszerének teológiai alkalmazásához kapcsolódnak. Életrajzi-szakmai visszaemlékezéseiben Dulles így vallott e nevéhez kapcsolódó módszertan lényegéröl:

„Míg a közelmúlt neoskolasztikus módszertana azt tartotta volna helyesnek, ha a
teológia egyetlen kép vagy fogalom mellett állást foglalva, az összes többi
alternativát mint téveset utasitja el, én egy párbeszédesebb megközelités mellett
álltam ki. Weigel atya meggyözött arról, hogy az egyház mint misztérium nem
foglalható bele fogalmi definícióba. Helyesebb különbözö képek és metaforák
sokaságával közeliteni hozzá, mivel minden ilyen megközelités az összetett
valóság egy korlátozott érvényü aspektusát ragadja meg. Valamilyen
reprezentáció kizárólagosságára törekedve - úgy gondoltam-bebetonozódnak
a különbözö teológiai iskolák ütközö nézetei, pedig egyikük igaza sem
abszolutizálható, ahogy egyikük igaza sem teljességgel téves.”

(DULLES 1996a, p. 118)

A modellanalízis módszerét a szerző először az egyháztanra (1974b), majd a kinyilatkoztatás teológiájára (1983a) alkalmazta, így itt mi is ezt a sorrendet követjük a fontosabb eredmények összefoglalása során.

Az egyházmodellekről szóló könyvében (The Models of the Church) Dulles különböző egyháztani gyökérmetaforákat vizsgál meg, majd az egyes „modellek” elemzéséhez az azokkal összhangban lévő autoritás-minták tárgyalását is hozzá kapcsolja (vö. DULLES 1987a, pp. 161-175). ${ }^{11}$ Az egyház intézményi modellje (societas), amely egy jól szervezett társadalmi csoport magas státuszba helyezett vezetöiként szemléli a püspököket, a hatalommal felruházott lelkipásztori hivatal formális tekintélyét hangsúlyozza: feladatuk vezetni a közösség istentiszteletét, megszabni az elfogadható tanbeli eltérések határait, és hivatalosan képviselni a közösséget. Az autoritás itt hierarchikusan kiemelkedik a közösségből. Az egyházat misztikus közösségként (communio) megközelítő modell azt hangsúlyozza, hogy az egyháznak Istennel egyesültnek kell lennie, s hogy ennek a kegyelemnek az erejével a tagoknak is egységet kell alkotniuk egymással. A püspöki tekintély ezzel összefüggésben mellérendelö, testvéri, animátori szerepet kap. Az autoritás az egyház egységének megóvása érdekében összhangot teremt a karizmák sokféleségében, a tanítói szerep mások meglátásainak a lehetőség szerinti integrálását is feltételezi. Az egyház szentségi modellje (sacramentum) szerint az egyháznak minden látható, jelszerü aspektusában - különösen a közösségi imádságban és istentiszteletben - Krisztus kegyelmének folyamatos életerejét és az általa ígért megváltás reményét kell megjelenítenie. Ezzel összefüggésben a püspök a felszentelt közvetítő szerepébe kerül, akinek nem a személyére vagy vezetői kvalitásaira, hanem a szakrális lefoglaltságára és kultikus szolgálatára kerül a hangsúly. A tanító személyében azt a Krisztust közvetíti, aki maga az Igazság. Ennek megfelelően az autoritás képviselője részéről e modell összefüggésében az emberi és lelki érettségre törekvés, illetve a szavak és tettek megfelelősége kerül mérlegre. Az egyházat az apostoli igehirdetés (kérügma) hírnökének tekintve, annak mindenekelött az Evangélium hirdetését kell folytatnia, és arra kell buzdítania az embereket, hogy hitüket Jézusba vessék, aki Úr és Megváltó. Ezzel összefüggésben a püspök úgy jelenik meg, mint evangelizátor és prófétai szónok, akinek a retorikai hozzáértése és hitelessége kerül megmérettetésre. Végül az egyházat szolgálattevőként (diakónia) szemlélve, annak hozzá kell járulnia az emberi közösségek és az egyén

11 A mű jelentőségéröl és recepciójáról lásd CAREY 2010a, pp. 251-256. 
világi életének átváltoztatásához, s az egész emberi társadalmat kell gazdagítania Isten országának értékeivel. Ezzel az egyházképpel a szociálisan érzékeny, közéletben is tevőleges szerepet vállaló püspök modellje van összhangban. A különböző egyházképek az egyház misszióját más-más hangsúlyokkal láttatják, ezért eltérő autoritás-modelleket vonzanak. A jezsuita teológus magisztériumról szóló elemzései tekintettel vannak az egyház valóságának a modellek által feltárt komplexitására, valamint arra, hogy ezek a modellek feszültségbe kerülhetnek egymással.

Dulles a tekintély témakörét könyvének 1987-es, második, bővített kiadásában biblikus ihletettségü egyháztani perspektívából gondolja tovább, amikor a korábbi egyházmodelleket beilleszti a tanítványság paradigmájába (vö. DULLES 1987a, pp. 206-207; 1982a, pp. 8-17). A tanítványság Dulles számára teljes életformát, elkötelezettséget, részvételt, formálódást, valamint a Krisztus tekintélyét közvetítő egyházi autoritásoknak szóló engedelmességet jelent. A jezsuita teológus felfogása szerint ez a tanítványság-paradigma megfelelően kifejezésre juttatja a másodlagos tekintélyekhez füződő kapcsolat spirituális valóságát, valamint a tekintély gyakorlásának szolgálat jellegét. Dulles szerint ez a gondolkodási minta különösen is alkalmas az autoritás pneumatológiai és szótériológiai dimenzióinak kiemelésére, valamint a hívők intézményes egyházhoz füződő személyes viszonyának megragadására, amikor fennáll az „elszemélytelenített” hierarchikus tekintélyi struktúrák félreértésének veszélye. Az egyházi kapcsolatrendszernek ez a szemléletmódja megfelel a tekintély (exusia) bibliai fogalmának és a II. Vatikáni Zsinat erre épülő felfogásának is. ${ }^{12} \mathrm{~A}$ tanítványság gondolatköre paradigmaként szolgálhat a hívő másodlagos tekintélyekhez füződő kapcsolatának leírásához, de ugyanakkor a másodlagos tekintélyek rendszere által közvetített elsődleges autoritáshoz való kapcsolódás leírásához is jól kiaknázható alapot kínál.

Az elsődleges, isteni autoritás (proto-autoritás) maga is többféleképpen közelíthető meg, ahogy Dulles arra a kinyilatkoztatás-modellekről szóló könyvében rámutatott (The Models of Revelation) ${ }^{13} \mathrm{~A}$ kinyilatkoztatást mint „tant” tárgyaló megközelítés (Doctrinal Model) szerint Isten előadói tekintélyt igénylő tanúként cselekszik, bizonyos értelemben tanítóként, aki ilyen természetủ tekintélye alapján elfogadást kér a szavára. Ez a tekintélyforma az ismeretközlő odafordulásában, Isten mindentudásában gyökerezik. A kinyilatkoztatásban foglalt hitletétemény üdvtörténetileg a Szentírásban és az Apostoli Hagyományban képeződik le, és a tanítóhivatal felelös felügyeletével, de a teljes egyházi közösség közreműködésével jut el különböző korok hívőihez. A kinyilatkoztatást mint „történelmet” tárgyaló modell (Historical Model) Isten nagy üdvtörténeti tetteire helyezi a hangsúlyt, amelyek üzenetét a hívő a történelem Istenébe vetett bizalommal fogadja. Ez a megközelítés az Isten cselekvőképességében, mindenhatóságában gyökerező tekintélyforma képzetét sugallja. E felfogás szerint a közvetítő egyházi autoritások tanúi Isten üdvtörténeti tetteinek, és csupán tanúi minőségükben közvetítői azoknak. A hivatali tekintély e felfogásban más természetủ és jóval szükebbre szabott szerephez jut, mint a tanító modell esetében. A ,tapasztalat”-központú modell (Inner Experience Model) szerint a kinyilatkoztatás közvetlen belső tapasztalatként érkezik meg az emberhez. Közvetlen találkozás a Szenttel, amely a bibliai és keresztény hagyomány szerint a próféták és főleg Jézus tapasztalatával egységben valósul meg. Az itt szerepet játszó tekintélyforma Isten önhitelesítő közvetlenségében rejlik. A közvetítő egyházi autoritások e modell esetében elsősorban a kollektív, közösségi tapasztalat letéteményesei és médiumai. A „dialektikus” modell (Dialectical Model) azt hangsúlyozza, hogy a kinyilatkoztatás Krisztusban, a megtestesült Igében érkezik, aki egzisztenciális választ vált ki saját magával kapcsolatban az emberből. Semmilyen véges dolog nem lehet kinyilatkoztatás, csak akkor, ha az Ige megszólal általa. Az itt szerepet játszó tekintélyforma Isten „verbális erejében” és transzcendenciájában gyökerezik. Az

12 Ez Dulles szerint jól látszik abból, hogy a zsinati dokumentumokban 27 alkalommal fordul elő a „tanítvány” (lat. discipulus) szó, minden esetben a „keresztény” szinonimájaként (lásd Dulles 1987c in EliADE et al. 1987, p. 363).

13 A mű jelentőségéröl és recepciójáról lásd CAREY 2010a, pp. 306-321. 
elsődleges isteni tekintély és a másodlagos egyházi tekintélyek között e megközelítésben olyan áthidalhatatlan távolság van, hogy bálványozásnak minősülne az utóbbiaknak közvetlenül az előbbihez rendelése. E modell képviselői - némileg ellentmondásos módon - a Szentírást gyakran olyan módon azonosítják Isten Igéjével, hogy az megkérdőjelezi a modell alapelveinek a következetes érvényesítését. Végül, a kinyilatkoztatást „új tudatállapotként” leíró modell (New Awareness Model) szerint a hívőben olyan perspektívaeltolódás megy végbe, amely hatással van a történelmi események értelmezésére. Ez a modell Isten szentségének transzformatív jelenlétében rejlö tekintélyi forma képzetét sugallja. A megközelítés képviselői kapcsolatot feltételeznek a kinyilatkoztatás és a „történelmi haladás” jelenségei között, és a másodlagos egyházi autoritások szerepét ebben az összefüggésben, az újraértékelések ösztönzőiként képzelik el. Amikor Dulles a modelleken keresztül mutatja be a kinyilatkoztatás sokrétü gazdagságát, akkor egyúttal az elsődleges autoritás összetett természetéről is sokat elmond, amely elemzés az ő felfogásában előkészíti a kinyilatkoztatás - szintén sokrétű - történelmi közvetítésének tárgyalását.

A kinyilatkoztatás-modellek azzal összefüggésben is mérlegre kerülnek, hogy miképpen tudnak számot adni az elsődleges autoritás és a másodlagos egyházi tekintélyek rendszere közötti közvetítésröl. Mindegyik modell a maga módján utal az isteni önközlés valamiféle médiumára, amellyel a vizsgált tekintélyi alakzatok kapcsolatba kerülnek. Annak mintájára, ahogy az egyházmodellek esetében Dulles a tanítványság átfogó paradigmájával mutatott rá a különböző megközelítések koherenciájára, a kinyilatkoztatás-modellek esetében a szimbolikus közvetítés gondolatát helyezi hasonló funkcióba. Milyen médiumok képzetét vonzzák magukhoz az egyes modellek? A doktrinális modell elsősorban kicsiszolt fogalmakra épülő, tételes állításokból építkező diskurzus világában helyezi el az isteni közlés és az emberi befogadás, illetve az egyházi közvetítés találkozását. A történelmi modell az üdvtörténeti események közegében véli beazonosíthatónak a kapcsolatot. A tapasztalati modell az ember belső világára, közvetlen élményeire utal hasonló értelemben. A dialektikus modell szerint elsősorban Jézus Krisztusban, mint megtestesült Igében jön létre az Isten és ember közötti lényegi találkozás. Az új tudatállapot modellje pedig a történelmi fejlődés értékteremtő elemeiben azonosítja be a kinyilatkozatás dinamizmusának közegét. Dulles arra hívja fel a figyelmet, hogy a szimbolikus közvetítés megközelítésmódja képes lehet önmagában egyesíteni a felsorolt modellek sok jó tulajdonságát. A szimbólum teológiai fogalmának pontosítását követően Dulles kijelenti, hogy a II. Vatikáni Zsinat nyomában olyan tekintély-teológiára van szükség, ahol a középpontban az Örök Ige voltaképpeni egyetlen autoritása áll, és ahol a teremtett, egyházi tekintélyek - a szimbólumok értelmében - áttetszőek az elsődleges autoritás irányában. ${ }^{14}$

A szimbolikus közvetítés kinyilatkoztatás-elmélet alapját képező gondolatának helyes megértéséhez ki kell emelni az egyéb interdiszciplináris összefüggésekböl és definiálni kell a szimbólum teológiai fogalmát (lásd DULLES 2005a, pp. 157-183). Dulles felhívja a figyelmet arra, hogy a szimbólumot gyakran tekintik az elme metaforikus vagy mitikus alkotásának, amely nem szükségképpen felel meg valamilyen létező dolognak. A Szentírás is gyakran él azonban a költői képzelet eszközével, és ez nem csökkenti az illető szakasz, illetve könyvek jelentőségét. Úgy tünik tehát, hogy nemcsak tettekben történt a kinyilatkoztatás, hanem az emberi képzelőerö inspirált alkotásaiban is. Amikor Jézus példabeszédeket mond az Isten Országáról, ilyen kinyilatkoztatott „történetek”, „képek” keletkeznek. Dulles azonban hangsúlyozza, hogy a kinyilatkoztatás költöi tartalmainak megengedése mellett fenn kell tartani a történelemmel való szoros kapcsolatát is. Ezért fontos hangsúlyozni, hogy elsősorban Krisztus Isten szimbóluma a világban, és ezt a kijelentést a „reálszimbólumok” szentségtani értelmében kell komolyan venni. A Dulles által képviselt szimbolizmusnak ugyanakkor nem csupán a krisztológiai, hanem az

14 Dulles egy vita-panel keretében fejti ki ezt a gondolatot: DuLles 1999a in MURNION 1999, p. 133; vö. DuLleS 1971 b, p. 100. 
antropológiai gyökérzete is jelentős: az emberi test szoros szimbólumok struktúrájára emlékeztető kapcsolatban van a hozzá tartozó emberi lélekkel.

Dulles nagy hangsúlyt helyez a kinyilatkoztatás és az egyházi tanítás összetett kapcsolatának tárgyalására, illetve a szimbolikus közvetítés gondolatának bemutatására. Az amerikai teológus a szimbólumközpontú megközelítéssel mutat rá az isteni önközlés sokrétű természetére, illetve a kinyilatkoztatás szükebb, kognitív dimenziójára:

„A vizuális és irodalmi szimbolizmussal összevetve, a doctrina viszonylag elvont közlésformát képvisel, amely mindig kapcsolatban marad annak a konkrétabb és képszerübb diskurzusnak a világával, amelyböl voltaképpen származik." (DULLES 1983a, pp. 222-223)

Az isteni önközlésben megjelenő misztérium az egyház autoritás-struktúráinak közvetítésével tagolt, hivatalos tanítás formájában képeződik le. A tanítás leírásához használt fogalmak egyrészt elégtelenek a misztérium leírására, másrészt azonban közvetítik azt, mert szimbólumok módján kezdenek müködni: kapcsolatot létesítenek a leírt misztérium és az adott történelmi helyzet között, amelynek maguk is származékai (vö. uo. p. 274). Az egyházi autoritás pluralisztikus modellje történelmiségében, a tanfejlődés szempontjából segít értelmezni a főszerepet játszó közvetítési folyamatot. Dulles szimbolikus realizmusként nevezi el ezt az episztemológiai alapállását.

Szent Ágoston nyomán Dulles episztemológiai tematikája az „elköteleződő vagy bevonódó megismerés" korunkban különösen aktuális problematikájára is kitér. Az amerikai teológus a keresztény tanítványság gondolatkörében helyezi el a hit teológiájának azt a mozzanatát, hogy van olyan természetü ismeret, amely csak a szeretetben való elköteleződés nyomán válik hozzáférhetővé, és amely a boldog színelátásban teljesedhet ki. A zarándokegyház támogatja az egyént azon az úton, ahol részesülhet ebben az ismeretben:

„A cél felé törekedve, az egyház elöre segiti tagjait azon az úton, amely a végsö nagy kinyilatkoztatás felé tart, melyben Isten az ö örök Fiának megdicsöült emberségén keresztül tárja fel magát." (DULLES 1980c in KeLLY 1980, p. 29)

Dulles később különösen a hit perszonalista és transzcendentális modelljeinek kidolgozása során tér vissza az elköteleződő megismerés témájának fejtegetésére.

Különösen érdekes kérdés Dulles számára, hogy az „identitás” és a „relevancia” egymással feszültségben álló szempontjai miképpen érvényesülhetnek az üdvtörténeti tanfejlődés során. A jezsuita szerző szerint a katolikus teológiában közismert tanfejlődési elméletek három fö típusba sorolhatók: a logikai, az organikus és a történeti szituácionalista megközelítések típusaiba (vö. DULLES 1978a, pp. 49-53). A logikai elméletek szerint a tanfejlődés tere csupán a szillogisztikus következtetésekre korlátozódik, amely következtetések a kinyilatkoztatás tételes tartalmából (propozíciók) indulnak ki. Luis de Molina és Francisco Marín-Sola két jellegzetes képviselője volt ennek az elgondolásnak. Az organikus szemlélet szerint a kinyilatkoztatás olyan isteni önfeltárulkozás, amely az üdvtörténet folyamán fokozatosan bontakozik ki a Szentlélek hatása alatt. Ennek az elméletnek jellegzetes képviselői voltak kezdetben Johann A. Möhler és John H. Newman, majd később Karl Rahner és Edward Schillebeeckx. A „történeti szituácionalista” elmélet a fentiektől eltérően a tanítás megfogalmazásának történelmi kontextusát ugyanannyira komolyan veszi, mint a hitletéteményből belső törvényszerüségeknek megfelelően kibontakozó tartalmat. Ez az elgondolás a fejlődést a hitletéteményben foglalt tartalom és ,az idők jeleiként” olvasható konkrét üdvtörténeti körülmények dialógusaként fogja fel. Dulles leginkább ezzel a harmadik megközelítéssel tud azonosulni, mert ebben

15 Lásd még ennek az előadásnak az utolsó, Christian Faith as Discipleship című részét a maga egészében is: DuLLES 1980c in KELLY 1980, pp. 24-29. 
látja annak lehetőségét, hogy a dogmákat a kinyilatkoztatás adott történeti körülmények között megvalósuló kifejeződéseként értelmezze. E harmadikba kívánja integrálni az előző kettő előnyeit.

Ebben a pályaszakaszban Dulles gondolati fejlődését az autoritás teológiája szempontjából legkarakterisztikusabban az 1978-ban megjelent The Resilient Church (1978a), és az 1982-ben publikált A Church to Believe In (1982a) címü könyvei dokumentálják. Amint az amerikai teológus életrajzírója megjegyzi, mindkét publikáció ahhoz az időszakhoz kapcsolódik, amikor Dulles a zsinat utáni első lelkesedéshullám teológiai túlzásait érzékelve, saját magát a neoskolasztikával szemben továbbra is kritikusan, de az amerikai liberális áramlatoktól szintén elhatárolódva, a mérsékelt közép vonalában pozicionálja (lásd CAREY 2010a, pp. 291-295, 323-326). ${ }^{16}$ E két kötetet a következőkben - kizárólag e tanulmány témájára fókuszáltan - együttesen összegezzük.

Dulles ebben az időszakban már továbbfejlesztett formában fejtegeti az autoritás teológiájának szerteágazó kérdéseit, amelyeket egyre következetesebben „az egyházi autoritás pluralisztikus modellje" címszó alatt tárgyal (vö. DULLES 1978a, p. 99; 1978d, pp. 264-281; 1978b, pp. 387-399). A jezsuita teológus továbbra is hangsúlyozza, hogy Krisztus minden teremtett autoritás ősforrása, amely megelözi az egyházi tekintélystruktúrát (vö. DULLES 1982a, p. 9). Ugyanakkor ezzel párhuzamosan szintén hangsúlyozandó, hogy a kereszténység olyan vallás, amelynek középpontjában a megtestesülés áll (incarnational religion), amely a tekintélyfelfogásra is hatással van. Az egyházi autoritások összetett és dinamikus rendszerének ilyen módon közvetítő szerepe van, amely az egyház szakramentális valóságának összefüggésében válik érthetővé. Dulles szerint a különböző másodlagos tekintélyhordozók kölcsönviszonyai, amelyek kreatív feszültséget és dinamizmust hoznak az egyház életébe, strukturálják ezeket az egymástól is kölcsönösen függő tekintélyhordozókat:

\section{„,keresztény szempontból nem az a kérdés, hogy el kell-e fogadni az autoritást, hanem inkább az, hogy miképpen azonositsuk be és miképpen viszonyuljunk az egyházi autoritásokhoz. Sok keresztény beleesik abba a hibába, hogy egyes tekintélyhordozókon átnéz, míg másokat pedig abszolutizál."}

(DULLES 1978a, pp. 94-95)

Történeti áttekintésben Dulles rámutat arra, hogy hol „hierokratikus” irányban, hol pedig „demokratikus" módon valóban történtek ilyen kisiklások (vö. uo. pp. 97-99). Az első tendencia az egyházi hivatal vezetői szerepét hangsúlyozta túl olyan módon, hogy közben háttérbe szorultak az egyéb tekintélyhordozók (bár azok jelentőségét teljességgel soha nem tagadták). A második tendencia az egyházi konszenzuskeresés szerepét hangsúlyozta túl, mintegy szembeállítva a hívők hitérzékének (sensus fidelium) funkcióját a hivatali tekintély szolgálatával.

Az egyházi autoritás-szerkezet pluralisztikus modelljét vizsgálva Dulles a pozitív és negatív szempontok felől egyaránt mérlegre teszi a „hierokratikus” és a „demokratikus” szélsőségeket. Bár az első tekintélygyakorlási minta megjeleníti és óvja az egyház ad extra egységét, ugyanakkor ad intra polarizálja a közösséget a hivatalviselők (ecclesia docens) és az alájuk rendeltek (ecclesia discens) megkülönböztetésére helyezve a hangsúlyt. Az amerikai teológus saját szavaival, ez a tekintélygyakorlási forma előmozdítja ,a doktrinális extrinzikizmust, amire sokszor vakon vállalt beleegyezésként (»blank check « theory of assent) is utalnak” (uo. p. 97; vö. DULLES 1989a in REESE 1989, p. 251). Ez a tekintélyi struktúra erősen aszimmetrikus módon a hivatalviselő autoritását hangsúlyozza, amivel párhuzamosan az egyén kritikai gondolkodása és intellektuális belátása alig juthat szerephez. Dulles szerint ennek az elmúlt évszázadokban sokszor domináns autoritás-konstrukciónak sok káros utóhatását ma is tapasztalhatjuk.

A demokratikus modell ezzel szemben kétségkívül tudatosítja az autoritás-rendszer szélesebb egyháztörténeti bázisának a jelentőségét, ezáltal aktivizálva az összetettségben rejlő lehetőségeket.

16 Dulles értékelése az egyház korabeli helyzetéről: DuLLES 1987b, pp. 642-649. 
Ugyanakkor ennek a tekintélygyakorlási mintának is egyháztani egyensúlyvesztés lehet a következménye, amennyiben túlhangsúlyozzák a laikus hívek testületi tekintélyét a rendszer egészében. Dulles számára mindebből az következik, hogy önmagában sem a hierokratikus, sem a demokratikus modell nem ragadja meg az egyház isteni kompozíciójának a lényegét, ezért szükség van a pluralisztikus autoritás-modell kidolgozására és érvényesítésére, hogy ezáltal kikerülhetőek legyenek az egyoldalúságok. Dulles meggyőződése szerint ez a modell hüségesebb a Szentíráshoz és az egyházi élet valóságához, mint bármelyik másik modell.

Amikor a másodlagos autoritások strukturált tárgyalásába fog, akkor Dulles első helyen a Szentírást nevezi meg, amelyet a keresztény doktrína referenciapontjának tekint (vö. DULLES 1978a, pp. 97-100). Ugyanakkor teremtett tekintélyhordozóként maga a Szentírás sem abszolutizálható. A többi másodlagos autoritáshoz füződő szoros kapcsolatát pedig az is mutatja, hogy a Szentírás csak a Hagyomány közegében tárja fel a maga teljes és hiteles értelmét. Dulles így a Szenthagyományt nevezi meg második helyen a teremtett tekintélyhordozók sorában (vö. uo.). A II. Vatikáni Zsinat integratív szemléletmódjának megfelelően a jezsuita teológus fontosnak tartja egyháztani összefüggésben is elhelyezni az apostoli hit imént említett tanúsítófórumait, így harmadik helyen a hitérzéket (sensus fidei fidelium) nevezi meg az autoritások sorában (vö. LG 12). Ennek a tekintélyi intézménynek a komolyan vétele alkalmas arra, hogy ellensúlyozza , a hatalomkoncentrációra való hajlamot, amikor egy szük uralkodó osztály akarja kisajátitani a vezetést az egyházban”, amellyel szemben szükségképpen megjelenik az „alávetett osztály”, akik az előbbiek aktív vezetésével szemben passzivitásra vannak kárhoztatva (vö. uo. pp. 97-98). Fontos azonban megjegyezni, hogy Dulles soha nem azonosítja a hitérzék egyháztani jelenségét a közvélemény és a kordivatok változó szeszélyeivel. Ezután Dulles azok szolgálatát tárgyalja, akik az autoritást mint egyházi hivatalokba kinevezett személyek hordozzák. Végül azok az egyházi személyek következnek, akik akadémiai jártasságuknál, illetve prudenciális képességeiknél fogva alkalmasak arra, hogy - egyénileg vagy testületileg - tekintéllyel szólásra emelkedjenek az egyházban. Ideális esetben az elöző csoporttal szoros összefüggésben az egyháznak vannak olyan tagjai is, akik ,prófétai belátásaiknál”, illetve sajátos karizmáiknál fogva tesznek szert tekintélyre az egyház ügyeinek a megvitatásában. Az utóbbi három kategóriát az kapcsolja össze, hogy ezek esetében egy-egy autoritással rendelkező individuumnak az egyházi közösség számára hasznos szolgálatáról van szó (vö. uo. pp. 97-100). Dulles különösen hangsúlyozta ezeknek az egymástól jól megkülönböztethető, egymásra visszavezethetetlen autoritás-formáknak az egymáshoz rendeltségét, valamint szerves egységét az egyház életében.

Dulles a „mérsékelt közép” iránti vonzódása jegyében kísérletet tett az egyház isteni alkotmányából fakadó, változhatatlan, illetve az üdvösségtörténet különböző korszakaiban a körülményekhez adaptálódó, változó elemeinek a fundamentálteológiai megkülönböztetésére. A pluralisztikus autoritásmodell vizsgálatával összefüggésben, ezt a ius divinum katolikus fogalmának elemzése útján látta kivitelezhetőnek. Az amerikai teológus meggyőződése szerint a tekintély egyháztani elemzése során számolni kell olyan alapvető mintázatokkal és intézményekkel, amelyek isteni rendelkezésre vezethetők vissza. Ezek egy része már az ősegyházban jelen volt, míg vannak olyanok is, amelyek később jelentek meg. Továbbá - Dulles szerint - lehetnek olyan egyházalkotó elemek is, amelyek egykor úgy jelentek meg, hogy akkor megfeleltek az isteni akaratnak, de később elvesztették legitimációjukat, mert egy későbbi korban immár nem feleltek meg az egyház céljainak (vö. DULLES 1982a, pp. 80-102). Ez utóbbi elképzelés a tanfejlődés Dulles-féle „szituácionista” megközelítésével hozható összefüggésbe (vö. DULLES 1978a, pp. 49-53). A klasszikus ius divinum problémakör ezen feldolgozása egyrészt az autoritás teológiájának az egyháztani beágyazásához, másrészt az ökumenikus kontextualizálásához kívánt hozzájárulni. Második pályaszakaszában Dulles egyaránt kitüntetett figyelmet szentelt az egyházi élet ad intra és ad extra dialogikus kihívásainak, amely érzékenység egyébként egész teológusi pályáján elkísérte (lásd DULLES 1965, pp. 300-315; 1988a, pp. 110-131; 1990b, pp. 54-59; 1996b). 
A jezsuita teológus katolikus elkötelezettségének és következetesen katolikus nyelvezetének köszönhetően úgy tünhet, hogy az egyházi tekintély pluralisztikus teológiájával kapcsolatban a szerző csak a katolikus diskurzus keretein belül gondolkodik (lásd DULLES 1986b, pp. 81-94; 1986c, pp. 375 378; 1986d, pp. 375-378). Ezért fontos hangsúlyozni, hogy Dulles szinte folyamatosan teszteli és kontextualizálja kibontakozó magisztériumteológiáját azon két- és többoldalú ökumenikus bizottsági munkák által, amelyeknek gyakorlatilag folyamatosan résztvevője. ${ }^{17}$ Ilyen irányú tevékenységei közül is kiemelkedő jelentőségü az amerikai katolikus-lutheránus vegyesbizottságban való részvétele, amely dialógus különösen értékes közös nyilatkozatokat fogalmazott meg a pápai primátus, az egyházi autoritás és a tévedhetetlenség szerteágazó témaköreiben (vö. DULLES 1974c, pp. 705-712; 1980b in EMPIE et al. 1980, pp. 81-100). Dulles rendkívüli karizmája, hogy más felekezetekhez tartozó kollégái számára képes volt hitelesen és közérthetően, de ugyanakkor elöítéletek és homályos sztereotípiák nélkül megfogalmazni a katolikus tanítás sarokpontjait. Ö maga a „kreatív hüséget” (creative fidelity) tekintette a gyümölcsöző és hiteles párbeszéd kulcsának (vö. DULLES 1982a, p. 102). Dulles az ökumenikusan müvelt teológia lényegét a következőképpen ragadta meg:
„A különbözö hagyományokból érkezö résztvevök helyesen teszik, ha a közös munka keretében fölvállalják a maguk konkrét meglátásait és hangsúlyait, miközben a többiek meglátásaiból és hangsúlyaiból is készek tanulni, természetesen mindig az adott közös témához kapcsolódva. Ez persze nem azt jelenti, hogy a résztvevők részéről egyházuk történeti álláspontjainak abszolutizálása lenne a megfelelö magatartás, különösen nem dogmatikailag definiálatlan esetekben. Ezzel szemben mindannyiuknak készen kell állniuk a saját álláspontjuk gazdagitására és alakitására, amikor a közös források igényes megvitatása nyomán az indokoltnak látszik. A résztvevoók azt is joggal igényelhetik, hogy az eltérö felekezetek részleges és problémás megfogalmazásait kezeljék feltételesen a források hiteles újraolvasása érdekében. Mindazonáltal egy olyan dialogikus teológia, amely az eredeti üzenet eltérö recepcióira is reflektál a különbözö gyülekezetekben, számomra becsületesebbnek és gyümölcsözöbbnek tünik, mint az olyan kísérletek, amelyek a bibliai alapokhoz való visszatérés jegyében új kezdet megkonstruálásával próbálkoznak." (DULLES 1980a, p. 42)

Láttuk, hogy a konvertita jezsuita teológusnak személyes családi motivációi is lehettek az ökumenizmus müvelésére, ahogy a kulturális változások érzékeny követésére is.

Dulles teológiai érdeklődésének fő irányait, illetve az egyházi autoritás-szerkezet kutatására irányuló erőfeszítéseit Yves Congar OP (1904-1995) személye és munkássága mindenki másnál erőteljesebben inspirálta (lásd CAREY 2010a, pp. 122, 143, 145, 163, 167, 171, 401, 420, 492, 501, 521). ${ }^{18}$ A hálás jezsuita tanítvány a domonkos mester - immár klasszikus - hagyományteológiai bevezetőjét a mü 2004es angol nyelvű kiadásának előszavában olyan időtálló munkaként méltatta, amely minden bizonnyal „, a téma valaha élt legnagyobb mesterének” a munkája (CONGAR 2004, p. x). ${ }^{19}$ Ennek a megállapításnak nagy a jelentősége, mert nem túlzás azt mondani, hogy Dulles tekintélyteológiai munkássága mind tartalmi, mind módszertani szempontból tökéletesen beilleszkedik Congar átfogóbb hagyományelméletének a keretei közé. Dulles hasonlóan drámai szavakkal fejezi ki Congar iránti háláját egy 2005-ös emlékkötetben:

„Nincs még egy 20. századi teológus, aki jobban megérdemelne egy ilyen emlékkötetet Yves Congarnál." (FLYNN 2005, p. 27-29)

17 Lásd Dulles 1978c in Trasy; KÜNG \& MeTZ 1978, pp. 91-101; Dulles 1976c, pp. 29-33; 1976d, pp. 26-29; 1976d, pp. 250-255; 1980d, 131-138; 1983b, pp.337-354; 1985c, pp. 7-8; Dulles 1979 in KÜNG \& MOLTMANN 1979, pp. 77-81; 1984d, pp. 607-633; 1976b, pp. 43-54; 1984b, p. 15.

18 Congar autoritás-teológiájának szisztematikus elemzéséhez lásd OELRICH 2011.

19 Magyar fordításban megjelent: CONGAR 2015. 
Congar még egyházmegyés kispapként, a párizsi Institut Catholique-on, 1921-ben kezdte meg teológiai tanulmányait, ahol Jacques Maritaint is hallgatta. 1925-ben lépett a domonkos rendbe, és 1931től kezdett teológiát tanítani. A fiatal francia teológust az ismeretelmélet, az egyháztan és az ökumenizmus kérdései kezdettől fogva intenzíven foglalkoztatták. 1952-ben, már szaktekintélyként, a nouvelle théologie nevü irányzat szerencsétlen megbélyegzésével együtt ő is korlátozásokat szenvedett. Befolyásos római teológusokkal fennálló szakmai konfliktusa enyhítésére elöljárói 1953-ban Jeruzsálembe küldték, hogy ott visszavonultabban folytathassa kutatásait. A francia domonkos alapos hagyománytörténeti forráselemzései jelentős mértékben ebből az időszakból eredeztethetők. XXIII. János pápa idején (1958-1963) azonban Congar munkásságának értéke már nem volt kérdés, így a teológus komoly szerepet kapott a II. Vatikáni Zsinat dokumentumainak szakértői előkészítésében. Peritusként több bizottság munkájában is részt vett. Ebben az időszakban adta közre a mindmáig alapmünek számító, kétkötetes monográfiáját a hagyomány fogalomtörténetéről, és az ebből kirajzolódó hagyományteológiai szintézisről: La Tradition et les traditions. I. Essai historique és II. Essai théologique (Fayard, Paris, 1960-1963). Egy évvel később, e szorosabban szakmai jellegü és igen terjedelmes munka kikristályosodott eredményeit rövidebb és didaktikusabb formában a szélesebb olvasóközönség számára is megjelentette. A traditio szót az apologetikus viták légkörében gyakorta elnagyoltan és pontatlanul használták, mintha a hagyomány egyszerüen a régmúlt generációk dokumentumokban tükröződő - többségi állásfoglalásainak minden időkre érvényes összességét képviselné. Congar felhívja a figyelmet arra, hogy a hagyomány a sensus fidei fideliumot, a hívek hitérzékét is magában foglaló teológiai valóság, amelynek a konkrét alkalmazása - ennek megfelelően - mindig lelki-szellemi megkülönböztetést is feltételez (vö. DULlES 1986e, pp. 240-242, 263; NEMZETKÖZI TEOLÓGIAi BizotTSÁG 2016, pp. 7-61).

A 19. század végétől kibontakozó ökumenikus mozgalom is felhívta a figyelmet az apologetikus hagyomány-teológia hiányosságaira és a naiv hagyományfelfogás belső ellentmondásaira. Ekkoriban a hagyomány teológiája iránti katolikus érdeklődés is megélénkült és elmélyült. A 20. század közepére, a II. Vatikáni Zsinat összehívásakor, reflektorfénybe kerültek a hagyomány pontos természetével kapcsolatos korábbi tisztázatlanságok, valamint a hagyományteológia egymással összeegyeztethetetlen, eltérő megközelítései. Congar műve rendkívül hasznos keretrendszert kínált Dulles számára az egyházi tekintély pluralisztikus elméletének a kidolgozásához (lásd DULLES 1988c in BOYLE \& KILCOURSE 1988).

\section{A harmadik szakmai életszakasz: Fordham University}

Avery Dulles harmadik pályaszakasza (1988-2008) föleg a hangsúlybeli újraértékelések és a szintézisteremtés terén hozott újdonságokat. Ahogy az első pályaszakaszában Michael Polányi, a másodikban Yves Congar, úgy a harmadikban leginkább John Henry Newman szellemi örökségének feldolgozása jelenik meg Dulles publikációiban (vö. CAREY 2010a, pp. 23, 32, 49, 89, 171, 224, 231, 243, 383, 433, 434, 483, 500, 511, 519, 536-541; lásd még DULLES 1990c, pp. 19-22). Továbbá, amint az eddigi korszakokat is összegző munkával tudtuk reprezentálni, most a 2001-ben II. János Pál pápa által bíborossá kreált szerző utolsó, Magisterium címü munkájára (2007) utalhatunk ilyen vonatkozásban (DULLES 2007). E kötet tankönyvi formában ugyan, de az említett újraértékelések és szintézis teremtés legfontosabb tanúbizonysága. Ezt a jelen tanulmány témája szempontjából központi jelentőségü munkát a következőkben részletesen tárgyaljuk.

A pályaszakasz közepén Dulles a Hittani Kongregációhoz tartozó Nemzetközi Teológiai Bizottság tagja lett (1992-1997), amivel párhuzamosan érdeklődése egyre intenzívebben fordult II. János Pál pápa tanítóhivatali tevékenyégének tanulmányozása felé. A jezsuita teológust az ebben az időben közreadott szentszéki dokumentumok recepciója is foglalkoztatta (DULLES 1990a). Dulles a szentszéki 
megnyilatkozások nyomán kialakuló szakmai vitákban egyre hangsúlyosabb feladatának érezte, hogy a tanítóhivatal „ügyvédjének” szerepében támogassa ezek pozitív recepcióját.

Miután Dullest a washingtoni Katolikus Egyetemen 1988-ban, 70 éves korában - az akkor érvényben lévő törvényeknek megfelelően - nyugdíjazták, jezsuita bázisközösségébe költözött a New York-i Fordham Egyetem bronxi kampuszán. Az egyetem vezetősége kifejezetten Dulles számára létrehozta a Laurence J. McGinley nevével fémjelzett professzori kutató állást a Vallás és Társadalom tanszéken. Ez a pozíció forrásokat és sok időt biztosított kutatásra, írásra, vendégelőadói felkérések elfogadására, és a Fordhamon csupán egy-két reprezentatív jellegü szeminárium, illetve előadás megtartását követelte meg (vö. DULLES 1999b, pp. 43-53; 1992e in BURGESS 1999, pp. 279-294; DULLES 1994b, pp. 36-46). Dulles befejezhette a modellanalízis módszerét a hit teológiájára is alkalmazó könyvét (The Assurance of Things Hoped For), amelyet a korábbi, hasonló módszertannal dolgozó munkái szerves folytatásának tekintett (DULLES 1994a). ${ }^{20}$ Ugyanebben az időszakban készült el a teológia metodológiai reflexióját tárgyaló kötetével (The Craft of Theology). ${ }^{21}$ Ökumenikus munkássága is összegzö fordulatot vett (vö. DULLES 1990d, pp. 169-201; 1992d in BURKE 1992, pp. 1-13).

Ebben a pályaszakaszában Dulles új hangsúlyokkal, valamint újabb és újabb kontextusban tért vissza az egyházi autoritás pluralisztikus modelljének gondolatköréhez (vö. DULLES 1999a in MURNION 1999, pp. 119, 132-134). Egyre fontosabbnak ítélte az erős tanítói autoritás-struktúra egységteremtő szerepét egy olyan egyházi közegben, amelyben a radikális individualizmus centrifugális erői a meghatározóak. Továbbá a keresztény hagyományt is új módon, a közösségelvü gondolkodás hajtóerejeként azonosította be a maga számára. Ez az irodalmi munkásságában megjelenő tónus Dulles értelmezésében visszavezethető a jezsuita gyökereire, az ignáci karizmához való hüségére, amelyben a jezsuita környezetétől kapott ösztönzés megújította (vö. DULLES 1993e, pp. 280-290; 1993c, pp. 99-109; 1995c, pp. 6-14). A környezetváltás hatásáról maga Dulles így ad számot:

„A domináns szekuláris kultúrával szembeni mérsékelten kritikus hozzáállásom azon ignáci elv rám gyakorolt befolyásának tulajdonitható, amely szerint ellene kell állni minden olyan erőnek, amely megpróbál eltávolitani a Krisztusnak szóló teljes átadottságomtól és a hierarchikus egyháztól. Szent Ignác szabályba foglalta, hogy épp az ellenkezöjét kell tenni annak, amire az evilági vagy hamis szellem inditaná az embert." (DULLES 1996a, p. 127)

Az ignáci lelkiség nemcsak a szekuláris befolyással szemben alkalmazkodóbb teológus kollégáitól távolította el Dullest, hanem egész látásmódjának alakulására is erőteljes hatással volt. A teológust ekkoriban intenzíven foglalkoztatta az a kérdés, hogy a jezsuita karizma miképpen emeli ki a tekintély és a szabadság, illetve a hierarchia és a részvétel dialektikáját (vö. NichOLS 1997, p. 203). Dulles bizonyos értelemben visszatért a prófétai hivatal - doktori kutatásai során már körüljárt - témájához, amikor hangsúlyozni kezdte az egyház életének prófétikus dimenzióját. A jezsuita lelkiség, a kritikai racionalitás, az intellektuális szabadság, valamint az egyház szervezeti kultúrájához bizonyos módon mindig hozzátartozó autoriter hozzáállás közötti egyensúly megtalálása volt ennek az időszaknak a tétje Dulles életében (vö. DULLES 1997e, p. 22).

Ezen a horizonton gondolkodva megállapítható, hogy Dulles ekkoriban intenzíven jelentkező érdeklődése II. János Pál pápa tanítóhivatali gyakorlata és megnyilatkozásainak teológiai tartalma iránt szintén összefüggésbe hozható az ignáci karizma hatásával. Dulles teológusi szinten megélt egyházias magatartása mindenképpen ebbe az összefüggésbe illeszkedik. A teológus szerepére vonatkozó elméleti reflexiói nyomán Dulles szorosabban is élni kezdte mind a magisztériumhoz füződő köteles lojalitást,

20 A hit modelljeiről magyarul lásd KRÁNITZ 2015, pp. 419-430.

21 Ez egy részleges, első kiadásban már 1992-ben megjelent, de a bővített formában terjedt el szélesebb körben: DULLES $1995^{2}$. 
mind azt a bölcs kritikai távolságtartást, amely a teológusi tanácsadói szerep gyakorlásához nélkülözhetetlenül szükséges.

A pluralisztikus tekintélyelmélet továbbgondolásának új kontextusaként jelentkezik ebben a pályaszakaszban Dulles újraevangelizáció iránti érdeklődése. A jezsuita teológus módszeresen tanulmányozta a tanítóhivatal evangelizációról szóló dokumentumait, különösen VI. Pál pápa Evangelii Nuntiandi kezdetủ apostoli buzdítását és II. János Pál pápa Redemptoris Missio kezdetű enciklikáját (vö. DULLES 1995b, pp. 397-400; 1992c, pp. 52-59, 69-72). Az Evangelii Nuntiandihoz írott elemzésében Dulles az evangelizáció hét jegyét említi. Elöször is, a fogalom ,, tágan értendö, amely nem csak missziós igehirdetésre vonatkozik, hanem katekézist, lelkipásztori és szentségi élettel kapcsolatos gondoskodást is magában foglal" (DULLES 1995b, p. 397). Az evangelizáció alanyaként az egész egyház értendő, hiszen az egyháznak egészében missziós karaktere van. E fogalom tehát kevésbé hierarchiaközpontú, mint a hagyományos misszió katolikus fogalma (vö. DULLES 1993b in MCDERMOTT 1993, pp. 170187). Harmadszor, az evangelizáció a személyes tanúságtétel erejére épül, ami kizár bármiféle szociális vagy hatalmi nyomást, amely sértené a vallásszabadság elvét. Az evangelizáció további négy eleme Dulles szerint a dialógus, a kultúrák misszionálása, a társadalmi struktúrák átalakítása, valamint a média megfelelő használata az egyház kommunikációjában. Ami az alapvető szemléleti kérdéseket illeti, az amerikai teológus három modellt különböztet meg az idegen kultúrákhoz való viszonyulás terén: a konfrontatív modellt, a szintézis-modellt és az átalakító szemléletü modellt (lásd DULLES 1984c, pp. 411). Dulles a harmadik modellt látja legalkalmasabbnak annak kifejezésére, hogy „a kereszténység bármely kultúrával szemben pozitiv elvárásokat támaszt, felszólítva a folyamatos megújulásra és reformra" (DULLES 1988a, p. 39). Bár a kereszténység konkrét kultúrákban ölt alakot, ő maga egyiktől sem függ, hiszen lényege szerint tágasabb azoknál. Az Evangélium viszont megtermékenyíti és átalakítja a kultúrákat, amely folyamat előmozdítása az egyház küldetésének szerves része (vö. uo. 4041).

II. János Pál pápa kreatívan továbbgondolta és alkalmazta VI. Pál örökségét (vö. DULLES 1992c, pp. 53-54). Dulles a két pápa gondolkodásmódjának megfelelően, szélesebb értelemben gondolkodik az evangelizációról, és II. János Pál nyomán különbséget tesz az evangelizáció és humanizáció kapcsolódó szempontjai között (vö. DULLES 1997d, pp. 723-724). Megállapítja, hogy a lengyel pápa beszédeiben 1983-tól kezdve került előtérbe az „új evangelizáció” gondolata, amelyet a jelen adottságaihoz alkalmazott, sokrétű misszióként értelmez. Ha II. János Pál sok mindenben követi is elődjének a felfogását, Dulles szemében a „prófétai humanizmus” mégis új, pozitív elem a gondolkodásában (vö. DULLES 1993d, pp. 6-11). Mivel ez a megközelítés az emberi méltóságból indul ki, joggal formálhat igényt egyetemes érvényességre, amely az egyház küldetését eleve a kultúrákhoz füződő kapcsolatában szemléli (vö. DULLES 1997c, pp. 19-32). Dulles az evangelizációs küldetés sikeres teljesítéséhez különösen fontosnak tartja az egyház ad intra erősen érvényesülő autoritárius szervezeti kultúrájának az ad extra meghaladását. A jezsuita szerző - az egész egyház missziós felelősségét kiemelő teológiai gondolattal összhangban - az evangelizáció témáját szélesebb olvasóközönséget megcélozva is feldolgozta (DULLES 2000a).

Amint az első pályaszakaszban a Humanae Vitae enciklika fogadtatásával kapcsolatos nemzetközi és amerikai viták, úgy e pályaszakaszból II. János Pál pápa Ordinatio Sacerdotalis címmel 1994-ben közreadott állásfoglalása, valamint annak recepciója jelent fontos esettanulmányt Dulles egyházi autoritáshoz füződő viszonyát illetően. Az apostoli levél megjelenése után a jezsuita teológus erősen védelmébe vette és jó apologéta módján támogatta a szentszéki nyilatkozatban foglaltakat, ahogy arról tucatnyi előadása és publikációja tanúskodik (vö. CAREY 2010a, pp. 506-513). A teológus kapcsolódó írásaiban természetesen tükröződött a magisztériumról alkotott felfogása (lásd DULLES 2003b; 1997a; 1997b). Az egyház belső vitáiban való aktív részvétel és az evangelizáció pasztorál-teológiai témájának kidolgozása mellett Dulles soha sem tagadta meg a fundamentális teológiai irányultságát. Ebben a 
pályaszakaszban a Newman bíboroshoz füződő személyes szimpátiája a nagy elöd módszeresebb tanulmányozására vezette Dullest. Ez a kutatási irány újabb lehetőséget kínált számára pluralisztikus tekintélyelméletének a továbbgondolására, integrálására.

Amikor a Fordham filozófiaprofesszora, Brian Davis OP egy kiemelkedő keresztény gondolkodókat bemutató sorozat szerkesztőjeként őt kérte fel a John Henry Newmanről tervezett kötet megírására, Dulles örömmel mondott igent a felkérésre (vö. CAREY 2010a, pp. 537-538). Az ekkor még intenzívebbé váló kutatómunka gyümölcseként 2002-ben megjelent Newman-monográfia az angol konvertita teológus szellemi portréját tette hozzáférhetővé szélesebb értelmiségi olvasóközönség számára (DULLES 2002a). Az 1890-ben, 89 évesen elhunyt bíboros szellemi örökségének súlyponti részét - a mai értelemben vett fundamentális teológián belül - a teológiai ismeretelmélet (episztemológia) témakörében helyezhetjük el (vö. uo. p. 150). ${ }^{22}$ Az idős, már anglikánból katolikussá lett Newman episztemológiai látásmódjában az egyház meghatározó apostoli kezdetei és kortárs empirikus-spirituális valósága között a hívő közösség mindenkori hittudata képviseli az eleven kapcsolatot, dinamikus folytonosságot (vö. DULLES 1994c in HAGEN, p. 321). ${ }^{23}$ Az üdvtörténeti zarándokútját járó egyház hittudata nem gyökértelen valóság, hiszen azt az egyház alapításával egybefonódó kinyilatkoztatásesemény alapozza meg, amely a Szentírás és a Szenthagyomány egybefonódó tanúságán keresztül férhető hozzá. Fontos hangsúlyozni, hogy önmagában a Szentírás és a Szenthagyomány egyike sem azonosítható az Isteni Ige kinyilatkoztatásban feltáruló misztériumával. Igaz azonban, hogy a megváltásban kapott új élet titka épp a Szentlélek müködésével különleges módon átjárt üdvtörténeti intézményeken keresztül hozzáférhető a számunkra. Newman episztemológiai vázlatában fontos mozzanat az, hogy a Szentírást és a Szenthagyományt két párhuzamos „csatornaként” szemlélő újkori nézetekkel szemben, azok elválaszthatatlan és egymást átjáró (perichoretikus) egysége mellett foglalt állást (vö. DULLES 2002a, pp. 120-121). Ez a belátás a protestáns környezetből származó szerzőnek azt a patrisztikus szemlélettel egybecsengő, egzisztenciális tapasztalatát tükrözi vissza, hogy önmagában a Szentírás kalauzolásával csak nehézkesen tudta megtalálni az annak teljes értelméhez, a hitbeli teljesség bizonyosságához vezető utat. E bizonyosság megtalálásához Newman szükségesnek tapasztalta az egyház hittudatában élő Hagyomány vezetését is, amelyet a krisztusi tanítványság lelkületének felöltésében, és így az Írás teljes értelmének megragadásában nélkülözhetetlen forrásnak tekint. Dulles számára a Newman által felvázolt teológiai horizont alkalmat kínált a pluralisztikus tekintélyelmélet továbbgondolására, illetve - a modern ember történeti tudatának megfelelő - üdvtörténeti távlatba helyezésére. Továbbá, Dulles a 19. századi elődtôl inspirálva tovább pontosította a saját „szituácionalista” tanfejlődés-elméletét (vö. DULLES 2002a, pp. 64-98).

A keresztény élet és a teológia egyszerre táplálkozik a Szentírás és a Szenthagyomány Isten Igéjét közvetítő tanúságából, miközben az egyház egyetemes hittudatának (vö. NEWMAN 1985, p. 73; idézi DULLES 1992b, p. 9) ${ }^{24}$ tekintélyt hordozó szellemi valóságával áll élő kapcsolatban. Az egyháztörténet legkritikusabb helyzeteiben ezen hittudat Szentlélek által általános vagy különleges formában asszisztált megnyilatkozásainak „hangja” az egyházi hierarchia doktrinális útmutatása. Newman a tanítóhivatal racionalitása mellett érvelt, amennyiben logikusnak tartotta feltételezni, hogy ha Isten kinyilatkoztatást adott az embernek, akkor a kinyilatkoztatott hitletétemény hiteles megőrzéséről is gondoskodott (lásd NEWMAN 1989, 75-92). ${ }^{25}$ Az angol teológus katolizálásában kulcsszerepet játszott a patrisztikus kor egyházának „teológiai hittudatával” való találkozás is. Az egyház életének első századai Newman

Ugyanezen mű 5-7. fejezetei adnak részletes kifejtést Newman teológiai episztemológiájának kulcspontjairól.

Dulles a következő müre tesz utalást: CONGAR 1968², pp. 166-167, 542; 1966, p. 211.

4 Newman egyháztanának hangsúlyos pneumatológiai dimenziója jut kifejezésre a hittudat (phronesis) patrisztikus eredetű fogalmának, és a sensus fidei fidelium egész teológiatörténetet végigkísérő egyháztani szempontjának előtérbe kerülésével. A konvertita bíboros sajátos hozzájárulása e terület teológiájához a tanításban való kreatív hüséget megalapozó „helyes következtetési érzék” (illative sense) gondolatának kidolgozása.

25 Ezt az érvelést hivatkozza DuLLEs 2007, pp. 4-5. 
számára nemcsak a látható egység történelmi lehetőségét garantálták, hanem - a teológia első virágkorán keresztül - annak igazi természetére is rámutattak. Newman a teológus egyházatyák tanítványa, amikor a teológiát az Isten Igéje előtti elcsendesedésként, kegyelem által kiérlelt érzékenységben adott válaszként, az egyház hittudatával való összhang kereséseként, és az Igazsággal való misztikus kapcsolatként közelítette meg. Korának az intézményi egyházat egyoldalúan előtérbe állító tendenciáival találkozva, Newman világosan kiállt a katolikus hagyomány teológiai hangsúlyai mellett. Egy teológiatörténeti zsákutcát jelentő korabeli felfogás szerint a Szentírásra és Szenthagyományra alapozott teológiai kutatás önmagában elvileg sem vezethet el az Igazsághoz, mert a teológiában semmi sem lehet bizonyossággá, amíg azt a hitletétemény értelmezésére hivatott formális tanítói tekintély meg nem erősíti. ${ }^{26}$ Ezt ellenpontozva Newman hangsúlyozza a felismert igazságban való bizonyosság hozzáférhetőségét minden keresztény és minden teológus számára, amelyet a hitérzék és a tanítóhivatal benső kapcsolata alapoz meg. Ismét csak személyes, a Katolikus Egyházba vezető igazságkeresésének drámai útján szerzett tapasztalatai tájolták be Newmant, amikor a patrisztikus kor teológiai életét és a korabeli hierarchia tanítói megnyilatkozásait tanulmányozva, sok kortársánál elmélyültebb, árnyaltabb képet alkotott a teológiai szabadságról és a tanítói hivatalnak az egyház egészében betöltött, az egység szolgálatában álló szerepéről. Ennek az árnyaltabb képnek a legsajátosabb vonása, hogy az egyházat tanító (docens) és tanuló (discens) részekre széthasító egyoldalú szemlélettel szemben, Newman rámutat az egyháznak a keresztség szentségében és a Szentlélek müködésében gyökerező lényegi egységére (vö. DULLES 2002a, pp. 83-98). Az ezen egységből fakadó - a laikus közösség, a teológusok és a hierarchia képviselöinek kölcsönös, dinamikus egymásra utaltságára épülő - egyháztan képezi Newman teológiai episztemológiájának alapvetését. Dulles megállapítja, hogy az egyháztan hitbeli ismeretekkel kapcsolatos, noetikus dimenziójának ez a tágas és mély összefüggésekre rávilágító, koherens szemlélete, és a szerző elméletet és életet folytonos dialógusban tartó tanúságtétele együttesen olyan „modern egyházatyává" avatják Newmant, akinek hangsúlyai több fent jelzett kulcsponton beépültek a II. Vatikáni Zsinat teológiai episztemológiáról szóló tanításába (vö. CAREY 2010a, p. 538).

Dulles éppen a Newmanről szóló könyvének kéziratán dolgozott, amikor értesítették, hogy II. János Pál pápa szándéka szerint, teológiai életmüvének elismeréseként, 2001. február 21-én a Római Katolikus Egyház bíborosává kreálják. Az egybeesésnek jelentősége van, hiszen Dulles az egy évszázaddal korábban élt Newmant mind életrajzi, mind szakmai stílusát tekintve lelki-szellemi rokonaként tartotta számon (vö. uo. pp. 536-539). Mindketten felső középosztálybeli családból származtak, elit egyetemi képzést kaptak, valamint konvertitaként lettek katolikusok. Teológiai profiljukat tekintve is hasonló a „mérsékelt közép” iránti karakteres vonzódásuk, amely a spektrum mindkét oldalával számtalan konfliktust eredményezett számukra. Newman és Dulles egyaránt elmélyült fundamentális teológiai irányultsággal közelítették meg az apologetikát, amelynek a két korszak vitás kérdéseivel összegfüggésben mesterei voltak. Elméleti érdeklődésük tengelyében állt a teológiai episztemológia tanulmányozása. Éppen a koruk egyházán belüli mediátori szerepük elismeréseként kapták meg mindketten a bíboros-diakónusi kinevezéssel járó rangos egyházi elismerést. Dulles a pápai gesztus nyomán nem csupán a nagy múlt századi előddel, hanem a II. Vatikáni Zsinatot előkészítő személyiségek közül Yves Congarhoz, Jean Daniélouhoz, Henri de Lubachoz, Hans Urs von Balthasarhoz, valamint Alois Grillmeierhez, Pietro Pavanhoz és Leo Scheffczykhez hasonló teológusbíborosokkal került egy sorba. Ö lévén az első áldozópapi rendhez tartozó, amerikai bíboros-diakónus, a megtiszteltetés rajta keresztül - áttételes módon - az egész „újvilági” katolikus egyháznak szólt (vö. uo. pp. 514-566).

Az amerikai New Catholic Encyclopedia a következőképpen méltatja Dulles bíboros teológiai életművét:

26 A 19. század második felétől a Római Teológiai Iskola képvisel ilyen típusú álláspontot Johann B. Franzelin SJtől, Louis Billot SJ-n át, a 20. század közepéig. 
„Dulles a kontextuális teológia müvelöjeként sorolható be, aki jellemzően kora aktuális kérdéseihez szólt hozzá. Teológiai írásai általában konkrét adatok, tényszerü információk, álláspontok, egyházi tanitáselemek, aktuális helyzetek felvonultatásával kezdödnek, majd gondos kritikai elemzésekkel folytatódnak, a megközelitések erös és gyenge oldalait egyaránt számba véve. Ezt követi a szerzö által javasolt megoldás, amely ha nem is az utolsó szó a témában, de meggyözö erejü. Ez a teológiai módszer nem csupán elméleti, hanem gyakorlati szempontból is hasznos, amennyiben aktuális kérdésekben segíti a tisztánlátást, konkrét elemzésekkel szolgál, miközben különbözö választási lehetöségek körvonalazódnak. Továbbá, a Dulles által felvetett megoldási javaslatok gyakorta közvetitö álláspontot képviselnek, a különbözö versengö nézetek erösségeinek egyesitésére, a korlátok okozta súrlódások minimalizálására törekedve." (FORD 2009, p. 277)

A jezsuita teológus „kontextuális irányultságának” a modellanalízis formájában kidolgozott metodológia adott karakteres formát. A módszer hátterében lévő gondolkodási stílus lényege, hogy különböző - sokszor hagyományosan szemben álló - teológiai iskolák szemléletmódjának komplementer összehangolására törekszik. Alkalmazására két fontos példával szolgáltak Dulles korábban már bemutatott egyháztani és kinyilatkoztatásteológiai publikációi. A teljesség igénye nélkül további példák a harmadik pályaszakaszból az evangelizációs, a kateketikai vagy az apologetikai modellek rendszerezése (lásd DULLES 2009, ch. 8, 9, 10).

Dulles egy fiatalkori paralízis-fertőzés utóhatásaként 2001-től már csak bottal, majd járókerettel tudott mozogni, míg 2007 őszétől egészségi állapota annyira megromlott, hogy hamarosan beszélőképességét is elveszítette (lásd CAREY 2010a, pp. 567-579; DULLES 2008, pp. 91-99). Eddig a pontig még intenzíven igyekezett befejezni a megkezdett munkáit - köztük a Magisterium címü könyvének kéziratát -, majd ágyhoz kötött beteg lett, és már csak egy különleges eszköz (lightwriter) segítségével, rendkívül lassan tudott kommunikálni. Az utolsó esztendő az összegzés és a halálra való derűs felkészülés időszaka volt a bíboros számára. Szakmai életpályájára visszatekintve a jezsuita teológus folytonosnak és következetesnek látta saját gondolati fejlődését, amelyben - szerinte - csak a különböző pályaszakaszok eltérő kihívásai hozták az eltérő hangsúlymozgásokat (vö. CAREY 2010b, p. 545). A jelen tanulmány szempontjából kiemelten fontos Magnum Opus valóban arról tanúskodik, hogy az autoritás teológiájának témájában ténylegesen megvan az életmü különböző rétegei között a Dulles által hangsúlyozott folytonosság (vö. KING 2016, p. 238). Amikor 2008. december 12-én, a Guadalupei Szent Szüz ünnepén a bíboros az Úrhoz költözött, az általunk vizsgált szempontból koherens szellemi örökséget hagyott maga után. Dulles halála után XVI. Benedek pápa a következő személyes méltató szavakkal biztosította részvétéről a gyászolókat:

„[Az egyház nevében szeretném kifejezni] mélységes hálámat a töle tanultakért, az itéleteiben megjelenö higgadt útmutatásáért, az Úr és az egyház iránt megmutatkozó szilárd szeretetéért, amely ugyanúgy megjelölte egész papi szolgálatát, mint hosszú tanári és kutatói pályafutását." (CAREY 2010a, p. 575)

Halálakor 25 könyv, 800-nál több szakcikk, számtalan recenzió és előadásszkript szerepelt Dulles hivatalos bibliográfiájában. ${ }^{27}$ Temetési szertartásán a szakmai életútját megjelölő „kreatív hüségét”, valamint a személyes tanúságtételét tükröző bíborosi jelmondatát emelték ki a megemlékezések (2Tim 1,12): ,, Tudom, hogy kinek hittem!” (Scio cui credidi!) (vö. CAREY 2010a, pp. 517, 574-579; továbbá lásd GUARINO 2009, pp. 40-46; CAREY 2010b, pp. 773-791).

27 Dulles rendszerezett bibliográfiájának hivatalos kiadása: KIRMSE; CANARIS \& MCCARRICK 2011. 


\section{Magnum Opus az egyházi autoritás teológiájáról}

Ahogyan már utaltunk rá, a magisztérium teológiájával kapcsolatos főbb eredményeit élete végén maga Dulles foglalta össze és tárgyalta újra egy százhúsz oldalnyi terjedelmü monográfia keretei között, amelyben saját korábbi témavázlatának kiegyensúlyozására törekedett. ${ }^{28} \mathrm{E}$ tanulmány utolsó része az egész életmü kontextusában helyezi el a Magnum Opus anyagát, amely az idős bíborosban megszülető érett szintézis tanúbizonysága.

Dulles 2007-ig nem írt átfogó tanulmányt az egyházi autoritás teológiájáról. ${ }^{29} \mathrm{Nem}$ adott módszeres történeti áttekintést az ilyen irányú kutatásairól, és a „magisztérium” szó szaknyelvi jelentését sem pontosította definíciószerủen, saját karakterisztikus felfogásának megfelelően. Ugyanakkor az egyházi tekintélystruktúra teológiai reflexiója már a „prófétai hivatalról” írott római doktori munkájával kezdődően az egyik fontos vissza-visszatérő téma volt a szerző által vizsgált kérdések tágas fundamentális teológiai horizontján (vö. CAREY 2010a, pp. 549-552). Az sem állítható azonban, hogy a jezsuita gondolkodó csak ad hoc helyzetekre adott válaszaiban foglalkozott volna a magisztérium témájával, hiszen az egyházi autoritás pluralisztikus elmélete Dulles fokozatosan fejlesztett témája volt, amelyet a zsinat nyomán jelentkező tekintélyteológiai vákuum miatt tartott időszerünek és fontosnak.

Bár Dulles hivatkozásain keresztül sokszorosan tanújelét adta annak, hogy jól ismeri mind a magisztérium intézménytörténetét, mind az intézményrendszer színes és sokrétü teológiatörténetét, publikációiban mégis elsősorban aktuális egyháztani összefüggésben foglalkozott a témával. Történeti utalásai csupán a hagyomány folytonosságának és aktualizálhatóságának alátámasztására szolgáltak az egyes konkrét kérdések tárgyalása kapcsán. Dulles gondolkodásában már pályája kezdetétől termékenyen kapcsolódott a magisztériumteológia karakteresen katolikus kidolgozása a téma ökumenikus reflexiójához.

Ami Dulles ilyen irányú munkásságának a Magnum Opus előtti hiányosságait illeti, kritikusai legalább négy általa elhanyagolt szempontra hívják fel a figyelmét (vö. DULLES 2000d, pp. 8-9): $:^{30}$ (1) felrótták neki, hogy az egyetemes egyház összefüggéseiben gondolkodva, hajlamos elhanyagolni az autoritás kérdéskörének a helyi egyházhoz kapcsolódó dimenzióját; ${ }^{31}$ (2) az előbbi hiányossággal szoros összefüggésben, elhanyagolja a „rendes és egyetemes tanítóhivatal” (magisterium ordinarium et universalium) arányos terjedelmü teológiai tárgyalását az ünnepélyes tanítóhivatali megnyilvánulások reflexiójához képest; (3) rövidre fogja a „rendes tanítóhivatal” (magisterium ordinarium) nem tévedhetetlen tekintélygyakorlási formáinak a tárgyalását; (4) sok utalást tesz az egyházi recepció folyamatának a jelentőségére, de gyakorlatilag nem írt terjedelmesebben e fontos témáról. Ezeknek a korábbi pályaszakaszban megfigyelt hiányosságoknak az újraértékelésére a - Dulles válaszaként értelmezhető - Magisterium részletesebb bemutatása után és annak tükrében fogunk visszatérni.

Dulles a rendelkezésre álló szakirodalmat illető kritikája alapján képet alkothatunk arról is, hogy a harmadik évezred elején ő maga mit hiányolt a fösodratú angolszász magisztériumteológiai munkákban. A Magisterium koncepciója és Dulles szerzői motivációinak megértése szempontjából különösen fontosak Francis Sullivan 1983-ban megjelentetett hasonló címü könyvéhez (SULLIVAN 1983), valamint Richard Gaillardetz 1997-ben megjelentett témába vágó monográfiájához füzött megjegyzései (GAILLARDETZ 1997). Sullivan munkáját Dulles közel negyedszázad múltán is a téma klasszikus, zsinat

28 A magisztériumról szóló monográfia magva ez a korábbi publikáció volt: DULLES 1988b in KERN; POTTMEYER \& SECKLER 1988, pp. 153-178.

29 Dulles fontosabb témába vágó cikkei a harmadik pályaszakaszából: DuLLES 1991c, pp. 289-299; 1991f, pp. 692696; 1989b, pp. 103-115.

30 Ebben a cikkében Dulles a szubszidiaritás egyháztani alkalmazása ellenében fejti ki álláspontját vitapartnereivel szemben. Az egyik részletes válasz a cikkre: ÖRSY 2000, pp. 9-15.

31 A témáról folyó vita áttekintéséhez magyarul lásd KeHL 2003, pp. 169-186. 
utáni feldolgozásának tekintette, amely rendszeres hivatkozási alapként szolgált számára (vö. CAREY 2010a, p. 550). ${ }^{32}$ Ugyanakkor Sullivan filológiai megközelítésmódja és szövegközpontú gondolkodási stílusa Dulles szemében széles teret engedett a fundamentális teológiai elmélyítésnek. ${ }^{33}$ Nem kevésbé volt fontos Dulles számára az egyházi autoritás teológiáját szorosabban érintő, 1989-2000 között megjelent szentszéki nyilatkozatok integrálása egy új monográfiába. Sullivan később a Magisterumra reagálva visszaigazolta Dulles ilyen irányú törekvéseinek a létjogosultságát (vö. SULLIVAN 2008, p. 727).

Az amerikai jezsuita Gaillardetz könyvének értékeiröl és hiányosságairól megformált véleményét egy általa írott recenzióból ismerhetjük meg (DULLES 1997f, pp. 836-837). Dulles szerint jól tájékozott, kiválóan megírt katolikus monográfiáról van szó, amely páratlan a maga nemében. Ugyanakkor felróható a szerzőnek, hogy a magisztérium 19. századot megelőző történetéről nem ad összefüggő áttekintést, illetve a kilencvenes évek első felének a II. János Pál pápa tanítóhivatali gyakorlata körül kialakult vitáit nem részletezi. Dulles szerint jelentkezik egy fontos újdonság II. János Pál pontifikátusában:

„A jelen pápának van egy nagyon érdekes és talán újdonságnak számitó eljárásmódja, amellyel a saját rendes tanitóhivatalát a püspöki kollégium "rendes és egyetemes tanitóhivatalának« megerösitésére használja fel, hogy igy az ex cathedra megnyilatkozások formalitásait kikerülve, definitiv tanitásokat hozhasson felszinre." (Uo. p. 836)

Dulles ezenkívül ellenpontozza Gaillardetz zsinati kollegialitás értelmezésének „decentralizációs” hangsúlyait a maga kúrialista magisztérium-felfogásának néhány elemével. Ezek pontosan azok a hangsúlyok, amelyek a jezsuita szerző 2007-es könyvében szembeötlően megjelennek.

Dulles Magisteriuma a szöveg tömörsége és a felhasznált szakirodalmi apparátus visszafogottsága miatt nehezen értelmezhető a magisztérium természetéről és hatásköréről folyó rendkívül komplex vitához fúzött szakmai hozzászólásként, ugyanakkor a tartalom letisztult mélysége és szakirodalmi pozicionálása - Dulles egész akadémiai munkásságával a háttérben - mégis komoly rangot adnak a monográfiának. Ennek jegyében tekintsük most át a könyv gondolatmenetét és tartalmát.

Az első fejezetben Dulles - a téma bonyolultsága miatt hermeneutikailag indokolt „elözetes megértést" szolgáló bevezetőként - felvillantja olvasóinak a magisztérium-teológia komplex összefüggéseit, amelyek ismerete nélkül a későbbi lineáris tárgyalás valóban nehezen lenne befogadható (vö. DULLES 2007, pp. 1-10). A tankönyvi elvárásoknak megfelelö, didaktikus szöveg hátterében azonban teológiai mélység rajzolódik ki: „vízjelként” már itt megjelennek Dulles pluralisztikus egyházi autoritás-modelljének körvonalai, amely gondolkodási minta azután az egész könyvön végig követhető:

\section{„A következö fejezetek olvasójának figyelmébe ajánlom a tágabb összefüggéseket, nehogy szem elöl tévesszük a magisztérium müködésének természetes kontextusát." (Uo. p. 9)}

A fejezet első pontja a tria munera téma által azonnal kapcsolatot teremt a Krisztusban megtalálható elsődleges isteni autoritás és a másodlagos egyházi autoritások közös tanítói-prófétai, megszentelőipapi, valamint kormányzati-királyi dimenziói között. A szerző a józan ész, a hit, majd a kinyilatkoztatásteológia összefüggésében helyezi el a címben megjelölt fötémát, rámutatva a magisztérium lényegi természetére és teológiai funkciójára. Ezt követően Dulles - a II. Vatikáni Zsinat szemléletmódjának megfelelően - a hitletéteményt tanúsító intézményekhez, a Szentíráshoz és a Szenthagyományhoz

32 Példaként lásd még Dulles Magisteriumának a következő oldalakon található hivatkozásait: 2007, pp. 2, 63, 71, $72,76,78,79,80,94$.

33 Sullivan maga is szerteágazóan továbbgondolta és újabb publikációkkal egészítette ki az említett alapmüvét, lásd például SULLIVAN: 1988; 1996; 2001; valamint a szerzö több tucat magisztériumteológiai szakcikkét.

34 Ugyanerről az újításról lásd DuLLES 1997a, p. 86. 
kapcsolja a hivatali tekintély bemutatását (vö. DULLES 2007, p. 8). A Dei Verbum 10. pontjának idézése a Magisterium gondolatmenetének elején a pluralisztikus modellt jellemző autoritás-dinamika bemutatására szolgál:

„Világos tehát, hogy Isten bölcs rendelkezése szerint annyira összetartozik és egymásra van utalva a Szent Hagyomány, a Szentírás és az Egyházi Tanitóhivatal, hogy egyikük sem lehet meg a másik kettö nélkül. Mind a három együttesen, de mindegyikük a saját módján, az egy Szentlélek tevékenységének hatására eredményesen szolgálja a lelkek üdvösségét." (DV 10)

A második fejezetben Dulles rátér a főtéma szentírási megalapozására: vajon volt-e az egyháznak már az apostoli korban működő magisztériuma? Hogyan kapcsolódtak Jézus istenemberi tanítói tekintélyéhez az apostolok? Milyen értelemben örökölték át az egyedülálló apostoli autoritást a következő generáció egyházi elöljárói? Milyen képet ad az Újszövetség a püspöki intézmény kialakulásáról, megszilárdulásáról, különösen a tanítói küldetés összefüggésében? Dulles a kapcsolódó szentírási adatok szükösségéből fakadó bizonytalanságokat is konstatálja. A sorok között megjelenik ebben a fejezetben az a fötéma szempontjából fontos kettősség, hogy egyrészt a mai keresztények számára áthagyományozott Újszövetség tekintélye alapján lehetséges rekonstruálni az apostoli kor autoritás-viszonyait, másrészt azonban éppen az apostoli igehirdetés átszármaztatott tekintélyének erőterében öltöttek formát a Szentírásba foglalt normatív tanúságtételek. Így amikor ma a sugalmazott szövegek vagy az Apostoli Hagyomány tekintélyéröl esik szó, akkor voltaképpen - az apostoli folytonosság (successio apostolica) láncolatának közvetítésével - Jézus legszorosabb tanítványi körének autoritás-forrásához kapcsolódunk (vö. DULLES 2007, pp. 11-20).

Dulles könyvének harmadik fejezete már azt a kérdést veti föl, hogy a magisztérium intézményi formái miként fejlődtek, illetve alakultak az évszázadok alatt (vö. uo. pp. 21-34). Az előző fejezettel ápolt folytonosság jegyében a történeti áttekintés az első három század szerzőinek a püspöki intézményről szóló legfontosabb tanúságtételeit veszi számba. Ezt követően Dulles rátér az egyetemes zsinatok, a pápaság, majd a skolasztikus korban kibontakozó új autoritás-struktúrák, illetve a Trienti Zsinat és a barokk teológia, majd a két vatikáni zsinat közötti időszak tárgyalására. Végső soron ez a fejezet 13 oldalon olyan - pápai autoritásra fókuszált - áttekintését adja a magisztériumteológia és a kapcsolódó egyházi intézményrendszer fejlődésének, amely nemcsak Dulles irodalmi munkásságában páratlan, hanem recenzorainak elismerését is kiváltotta (vö. CAREY 2010a, pp. 550-552).

A Magisterium negyedik fejezete felveti az alapvetö - és történetileg nézve igen komplex - kérdést, hogy kik tartoznak hozzá a tanítóhivatalhoz abban az értelemben, hogy felhatalmazásuk van a tanító Krisztus nevében nyilatkozni. Dulles a hierarchia magisztériumának sajátosságát annak szakramentális természetében és az általa adott tanítás - jogilag is leírt - kötelező erejében látja. Ezzel összevetve a teológusok testületének az állásfoglalásai nem hordoznak doktrínaalkotó autoritást, bár bizonyos analóg értelemben vett - magisztériumi hozzájárulásról mégis csak beszélhetünk ezekkel kapcsolatban. A teológusok összetett egyházi funkciójának elemzése során a szerző két esettanulmányon keresztül pontosítja a mondanivalóját: kitér az egyházatyák konszenzusos autoritásának elemzésére, valamint a hívek testületének sensus fideliumon alapuló tekintélyi tanúságtételére. Az utóbbi kategóriában különösen érdekes lehet a szent emberek, misztikusok teológiájának a pluralista autoritás-elméleten belüli elhelyezése (vö. DULLES 2007, pp. 35-46).

A következő fejezet Dulles perspektívájából megvizsgálja azt a klasszikus kérdést, hogy a hierarchikus magisztériumon belül miképpen tagolódnak a tekintélygyakorlás alanyai. A tárgyalás első felében a szerző tömören bemutatja a püspöki kollegialitás tanának fejlődését a kezdetektől a II. Vatikáni Zsinatig. Már a kollegialitástan összefüggésében, ezt követően kerül sor a pápa tanítóhivatalának tárgyalására. Dulles ehhez kapcsolva jellegzetes módon kitér a szentszéki dikasztériumok pápát segítő kvázi-tanítóhivatali szerepének a teológiai elemzésére is. A tárgyalást a püspökök - szinodalitás 
jegyében együttmüködö - csoportjainak és az egyes püspökök tanítóhivatali szerepének elemzése zárja (vö. uo. pp. 47-58).

A könyvben ezután következik a pápával egységben lévő püspöki kollégium különböző tanítói aktusainak paramétereit és hatáskörét tárgyaló szakasz, amely a kötet leghosszabb, 21 oldalas fejezete. Egymásba füzve szerepelnek a tárgyalásban a dinamikusan szemlélt hitletéteményt, a tanítói autoritás „hit és erkölcsre” korlátozott hatáskörét, valamint - az átfogóbb asszisztencia-tan részeként - a tévedhetetlenségi karizma müködését elemző részek. Két - Dullesre jellemző - karakterisztikus része a fejezetnek a magisztérium hármas funkcióját tárgyaló szakasz (tanúskodás, hivatalos magyarázat, a hitletétemény integritásának őrzése), valamint a társadalmi tanítás doktrínán belüli státuszát megvilágító néhány bekezdés (vö. uo. pp. 59-82). Az amerikai teológus fontosnak tartja az egyházi tanítás-korpusz összetett valóságának kellően differenciált kezelését, körültekintő hermeneutikáját, amelyet az egyház szervezeti kultúrájában a barokk kortól kezdve erősen meggyökerezett pápa- és infallibilitasközpontúság kifejezetten akadályoz. Az episztemológiai hierarchia elvek (hierarchia veritatum, qualificatio theologica) gyakorlatba való átültetése, valamint a tanfejlődés motorjaként számításba vett öt tekintélyi intézmény összjátékára fordított figyelem (vö. DV 8) segíthet a teológiai tisztánlátásban.

A hetedik fejezet központi kérdése: vajon a különböző típusú és besorolású magisztériumi megnyilatkozásoknak a hívők milyen válaszai és kötelmei felelnek meg? A tárgyalás elején Dulles aktualizáló céllal röviden áttekinti a teológiai jelzetek újkori hagyományát, majd ismerteti a 20. század végének azokat a szentszéki dokumentumait, amelyek a tekintélyi, illetve bizonyossági fokok régi-új doktrínáját beiktatják az egyház jelen gyakorlatába (vö. CDF 1989, pp. 661, 663; 1990, pp. 117, 119126; JOHN PAUL II 1998, pp. 113-116). ${ }^{35}$ Úgy tünik, hogy magát ezt a tanításelemet Dulles a tekintéllyel kimondott megnyilatkozások kategóriájába sorolja. A Magisteriumnak ez a fejezete teljességgel az említett szentszéki dokumentumokra fókuszáltan ismerteti a különböző tanításelemeket rendszerező hivatalos sémát, feltünően szükre szabva a kötet más részeiben jelen lévő teológiai elemzéseket. Egy kivételt jelent ez alól Dullesnek az a megjegyzése, amellyel bírálja a szentek kanonizációjának tekintélyi besorolását (definitív tanítás, történeti kapcsolat jogán), amely példa szintén az egyik említett hivatalos dokumentumban jelenik meg (vö. DULLES 2007, p. 91). A könyv hetedik fejezetében tapasztalt visszafogottság oka lehet, hogy az itt előkerülő kérdések szorosan kapcsolódnak az „egyházi egyet nem értés" (dissensus) fajsúlyos problematikájához, amely téma a tárgyalás utolsó pontja (vö. uo. pp. 83100).

A könyv nyolcadik fejezete - szükebben értelmezve - körüljárja, hogy az egyházi autoritás közösségi szolgálata hogyan valósul meg a recepciós folyamatokban. Tágabban értelmezve azonban ez a lezáró fejezet Dulles kommunió-egyháztanra épülő pluralisztikus autoritás-modelljét összegzi és tárgyalja újra a hivatali tekintély szempontjából. A szerző ismét felvonultatja az egyházban konstitutív szerepet játszó összes „másodlagos” autoritás-formát, amelyek dinamikus összjátékát a szoros értelemben vett recepciós folyamatok összefüggésében értelmezi. Az egyházi recepció időleges „elakadásának” vagy „megvonásának” jelenségei is egyháztani összefüggésbe kerülnek. Az elmondottakon túlmenően mindjárt a fejezet elején - az elsődleges, isteni autoritás témája is előkerül, amennyiben maga a hit ezzel összefüggésben recepciós folyamatként értelmezhető. Dulles abban is hű marad önmagához, hogy a recepció teológiai jelenségét a fejezetben végül ökumenikus szempontból is megvilágítja, ami a katolikus magisztériumteológia összefüggésében nem kis kihívást jelentő feladat (vö. uo. pp. 101-116).

Immár Dulles autoritás-teológiát szintetizáló főmüvének tükrében újra föltehetjük a kérdést, hogy vajon a fejlemények nyomán mit mondhatunk az őt ért korábbi bírálatokkal kapcsolatban? Vajon sikerült-e kiegyensúlyoznia témavázlatát azokon a pontokon, ahol abban saját maga is hiányosságokat vett észre? A Magisteriumnak mindenképpen javára írható, hogy két fejezetben, áttekinthető

35 Továbbá félhivatalos magyarázatként lásd RATZINGER \& BERTONE 1998, pp. 116-119. 
terjedelemben, de mégis szubsztanciális történeti áttekintést ad a fötéma fundamentális teológiai elemzésének előkészítéseként. Dulles pusztán ezáltal is hozzájárult a teológiai szakág megközelíthetőbbé tételéhez, mivel a kapcsolódó szakirodalom mostohagyermeke az autoritásra fókuszált egységes intézmény- és teológiatörténeti narratíva megalkotása. Hasonlóan sikeresnek mondható Dulles egyházi recepciós folyamatokról adott összefoglalója, amelyet a pluralisztikus modell gondolatvilága által a szerzőnek sikerült összekapcsolnia a mü egészével, így kipótolva tematikájának a korábban mások által felrótt hiányosságait.

Kérdéses azonban, hogy hozott-e újdonságokat a könyv az egyetemes egyház és a helyi egyház teológiai egyensúlyának tárgykörében. A kritika az volt Dullesszel szemben, hogy miközben az egyház központi kormányzatára összpontosítja figyelmét és figyelmen kívül hagyja a jelenlegi - történelmileg sokszor esetlegesnek tűnő - struktúrákat, valójában megtagadja azokat a kollegialitás tanából következő konzultációs lehetőségeket, amelyek a számára is fontos ökumenikus kapcsolatkeresés sarkalatos kérdései (vö. ÖRSY 2000, pp. 9-15). ${ }^{36}$ Dulles bizonyos mértékig egyetért ezzel az észrevétellel, és fölvállalja, hogy a harmadik pályaszakaszban már jobban foglalkoztatta öt a katolikus világ belső egységének kérdése, mint az ökumenikus kapcsolatkeresésé:

„Be kell vallanom, hogy a többpólusú és inkulturációt igénylö világegyház felé
haladva még nagyobb szükségét érzem az egységet szolgáló erös egyházi
hivatalnak, mert ez lehet képes megóvni a különbözö régiókban élö katolikusokat
a kölcsönös elidegenedéstöl.” (DULLES 2000b, p. 13)

Ezzel együtt is igaz, hogy az ötödik fejezet utolsó harmada a korábbiaknál nagyobb figyelmet fordít a tanítóhivatal helyi egyházakhoz kapcsolódó szerveinek a tárgyalására, a hetedik fejezet második fele pedig a püspökök rendes tanítóhivatalával foglalkozik. A kollegiálisan gyakorolt „rendes és egyetemes tanítóhivatal”, illetve a pápa rendes tanítóhivatalának kritikusok által korábban számonkért témája is arányos tárgyalást kapott a hatodik fejezet közepén. Ilyen módon a jezsuita szerző jól érzékelhetően igyekezett megfelelni a teológusközösség elvárásainak, miközben saját kiforrott témavázlatát sem tagadta meg.

Dullesnek az egyházi autoritás szerepéről kidolgozott teológiája - ismét az életmü tágabb összefüggéseire tekintve - az egyház II. Vatikáni Zsinatot megelőző autoriter szervezeti kultúrájának meggyengülése nyomán, a zsinattól kapott ösztönzésekböl fakadó útkeresés összefüggésében öltött alakot, a tekintély jellegzetes ,pluralisztikus modellje” körül kikristályosodva. Megkerülhetetlennek tűnt a magisztérium fundamentális teológiájának egy inkluzívabb, átfogó egyháztani keretbe ágyazott újragondolása, amely képes tekintetbe venni a tanítóhivatali megnyilatkozások történetiségének tényeit, és képes tanulni az egyháztörténetileg részben változó struktúrák tapasztalataiból (vö. DULLES 1971b, p. 114). Dulles a zsinatot közvetlenül követô időszak kihívásaira így emlékszik vissza:
„Ami engem a II. Vatikáni Zsinatot követö mozgalmas évtizedben foglalkoztatott, az inkább teológiai, mintsem pasztorális indittatásból fakadt. Nehéz kérdések jöttek felszinre a teológiai közösségben elharapódzó egyet nem értések (dissensus) miatt. Van-e a teológusoknak valamilyen tanitói tekintélye vagy csak a hierarchikus magisztérium tanitó szerv az egyházban? Milyen kötelezö erö tulajdonitható a pápai tanításnak, amikor Péter utóda nem szorosan a kinyilatkoztatásról nyilatkozik, vagy amikor nem tart igényt tévedhetetlenségre?" (DULLES 1996a, p. 117)

A jezsuita teológus egy erősen polarizált és dinamikusan változó teológiai diskurzusban igyekezett megtalálni és képviselni a „stratégiai közép” álláspontját, amely egy életmü távlatában nem is annyira statikus centrizmusnak, mint inkább mozgó referenciapontnak mutatkozott (vö. MASSA 2007, pp. 932951). Ahogy arra az életút áttekintése során rámutattunk, Dulles igyekezete mindig az egymással

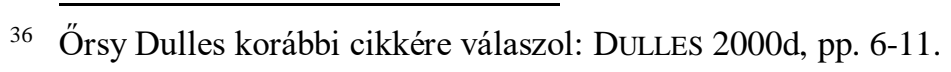


kölcsönhatásban álló hagyománybeli folytonosság és kulturális változások „egyensúlyi pontjának” keresésére irányult. Nem csupán Dulles belső fejlődése, hanem a zsinat utáni egyházi élet alakulása is úgy hatott, hogy ez a fundamentális teológiai centrizmus a szerző figyelmét első pályaszakaszában a „változás”, míg harmadik pályaszakaszban a „folytonosság” hangsúlyozása felé irányította. Ez a hangsúlymozgás egy felületesebb egyházpolitikai értékelésben törvényszerủen megkapta a jobbratolódás címkéjét. Dulles azonban mindkét oldali kritikusaival szemben ragaszkodott a maga következetes centrizmusához (vö. CAREY 2010a, p 545).

Mindenféle Dullesnél kimutatható hangsúlymozgástól elvonatkoztatva állítható, hogy a szerzőnek a „kapcsolatiságba ágyazott tekintélyfelfogása”, az egyházi autoritás szerepét tárgyaló teológiája a három pályaszakasz távlatában vizsgálódva is nagyfokú konzisztenciát mutat (vö. uo. pp. 549-550; KING 2016, p. 238). Egy általánosabb tekintélyelmélet horizontja elött, a lehatároltabb magisztérium-teológia különböző mozaikkockái - megfelelő gondossággal illesztve be azokat a maguk összefüggésrendszerébe - egységes képpé rendeződnek. Az amerikai teológus soha nem tagadta meg vagy vetette el korábbi állításait, nem is igazította ki azokat, hanem inkább a korábbi fontos belátások finomítására törekedett, amikor úgy érezte, hogy a magisztériumra vonatkozó elgondolásait a tanítóhivatali dokumentumok nyelvezetével és tartalmával kell szorosabb összhangba hoznia. Más esetekben éppen az egyházi tekintélyek megnyilatkozásai és az azok nyomán kialakult viták hoztak Dulles számára olyan tapasztalatokat, amelyek magisztérium-teológiájának finomhangolására késztették. Egy életút távlatában a jezsuita teológus hol a pápaságra, hol a hitérzékre, hol a teológusok vagy a püspöki konferenciák szerepére fókuszáltan gondolta tovább a főtéma összefüggéseit. Dulles „félhivatalos” történész-teológus életrajzírója, Patrick W. Carey az életmü egészével kapcsolatban így összegez:

„A részletek megitélésén túl, az életút egészére rátekintve néhány dolog világos. Dullest erösen alakitotta családjának hagyománya, megtérésének tapasztalata a Harvardon, továbbá az ignáci lelkiség, amelybe bevezetö képzést kapott, és amivel egész további életében azonosult. Meghatározó volt életútjára nézve a jezsuitáknál kapott teológiai képzés, valamint a II. Vatikáni Zsinat tapasztalata, amelyre egész teológiai gondolkodása irányult. Dulles az amerikai katolikusok számára (és mások számára is) a zsinati gondolatok elsödleges értelmezöjeként jelent meg, leforditott könyvein és cikkein keresztül messze az angolszász világ határain túl is elérve az olvasókat." (CAREY 2010a, p. 578)

Konkrétan a tanítóhivatal teológiájára vonatkozóan pedig a bíboros következő szavai jelzik az érett szintézis szellemiségét:

„A magisztériumnak fontos szerepe van az egyházon belül abban, hogy örködjön Isten népének a belsö és az Úrral való egysége fölött. Nem töltheti be a küldetését másképp, csak ha aláveti magát a Szentírásnak és a Hagyománynak, és ha él az imádság és a szentségi élet eszközeivel. A lelkipásztorok a kommunió egyszerü szolgálattevöi. Mint egy karmesternek, nekik is követniük kell a zeneszerzö által megirt kottát. Akkor tölthetik be a feladatukat, ha készséges közösségre találnak, amelynél a hangok sokasága harmonikus kórusmüvé olvad össze. Az egyház az ö vezetésükkel a trónon ülö Bárány dicséretét zengi, amig el nem jut az Örök Városba, ahol magisztériumra már nincs is szükség, mivel mindannyian saját szemükkel fogják látni a misztériumot, amelyben most még csak hisznek." (DULLES 2007, p. 113) 


\section{Irodalom - References}

1. Elsődleges források Avery Dulles életművéhez

Önálló müvek

Dulles, A. (1982a): A Church to Believe In. Discipleship and the Dynamics of Freedom. Crossroad Publ. Co., New York.

Dulles, A. (1971a): A History of Apologetics. Corpus Books, New York.

DULLES, A. (2005a): A kinyilatkoztatás modelljei. Vigilia Kiadó, Budapest.

DULLES, A. (1996a): A Testimonial to Grace and Reflections on a Theological Journey. Sheed \& Ward, Kansas City (MO).

Dulles, A. (1963): Apologetics and the Biblical Christ. Woodstock Paper 6., Newman Press, Westminster (MD).

Dulles, A. (2003a): Az egyház modelljei. Vigilia Kiadó, Budapest.

DULLES, A. (1974a): Church Membership as a Catholic and Ecumenical Problem. Marquette University Press, Milwaukee (WI). doi:10.5840/pmlt197462

DuLLES, A. (2009): Evangelization for the Third Millennium. Paulist Press, New York - Mahwah (NJ).

Dulles, A.; J. M. DEMSKE \& R. J. O'CONNELL (1955): Introductory Metaphysics. Sheed \& Ward, New York.

Dulles, A. (2002a): John Henry Newman. Continuum, London - New York.

Dulles, A. (1997a): John Paul II and the Teaching Authority of the Church. Like a Sentinel. Campion College, University of Regina, Regina.

Dulles, A. (2007): Magisterium. Teacher and Guardian of the Faith. Sapientia Press Ave Maria University, Naples (FL).

Dulles, A. (1983a): Models of Revelation. Doubleday \& Co., Garden City (NY); reprinted (1992a): Orbis Books, Maryknoll (NY).

Dulles, A. (1974b): Models of the Church. Doubleday Image Books, Garden City (NY); Expanded edition (1987a): Doubleday, Garden City (NY).

Dulles, A. (1941): Principles Concordiae. Pico della Mirandola and the Scholastic Tradition. Harvard University Press, Cambridge (MA). doi: $10.1086 / 358609$

Dulles, A. (1990a): Report of the Catholic Theological Society of America Committee on the Profession of Faith and the Oath of Fidelity. Catholic Theological Society of America, Chicago (IL).

DULLES, A. (1968a): Revelation and the Quest for Unity. Corpus Books, Washington (WA).

Dulles, A. (1969a): Revelation Theology. A History. Herder and Herder, New York.

Dulles, A. (1994a): The Assurance of Things Hoped For. A Theology of Christian Faith. Oxford University Press, New York.

Dulles, A. (1985a): The Catholicity of the Church. Clarendon Press, Oxford.

Dulles, A. (1992b): The Craft of Theology, From Symbol to System. Crossroad Publ. Co., New York.

Dulles, A. (19952a): The Craft of Theology. From Symbol to System. Expanded version, Crossroad Publ. Co., New York.

Dulles, A. (1967a): The Dimensions of the Church. Newman Press, Westminster (MD).

Dulles, A. (2000a): The New World of Faith. Our Sunday Visitor Publ., Huntington (IN). 
Dulles, A. (1961): The Protestant Churches and the Prophetic Office. Experta ex dissertation, Woodstock, Woodstock (MD).

Dulles, A. (1988a): The Reshaping of the Catholicism. Current Challenges in the Theology of Church. Harper \& Row, San Francisco.

Dulles, A. (1977a): The Resilient Church. Doubleday, Garden City (NY); (1978a): Gill \& Macmillan, Dublin.

Dulles, A. (2003b): The Splendor of Faith. The Theological Vision of Pope John Paul II. Crossroad Publ. Co., New York.

Dulles, A. (1971b): The Survival of Dogma. Doubleday, Garden City (NY).

Dulles, A. (1996b): The Travails of Dialogue. Ninth Annual Fall McGinley Lecture, Fordham University, Bronx - New York; Pamphlet (1996b): Fordham University Press, New York.

Dulles, A. (1997b): Truth as the Ground of Freedom. A Theme from John Paul II. Acton Institute, Grand Rapids (MI).

Dulles, A. (1986a): Vatican II and the Extraordinary Synod. An Overview. Liturgical Press, Collegeville (MN).

\section{Cikkek, kötetben megjelent tanulmányok}

Dulles, A. (1996c): A hit egyházi dimenziója. Communio, 4(4): 28-37.

Dulles, A. (2015): A hitaktus kognitív dimenziója. Teológia, 49(3-4): 163-172. (ford. Bagyinszki P. Á.)

Dulles, A. (1987b): A nyolcvanas évek egyháza. Vigilia, 52(9): 642-649.

Dulles, A. (1978b): Authority and Criticism in Systematic Theology. Theology Digest, 26: 387-399.

DuLLES, A. (2005b): Az Eucharisztia: Jézus élő ajándéka. Communio, 13(2-3): 100-111.

Dulles, A. (2006): Az ignáci karizma és napjaink teológiája. In: SZABÓ F. \& BARTÓK T. (szerk.) (2006): Jezsuiták Szent Ignác nyomdokain. Szent István Társulat, Budapest, pp. 173-188. A cikk a szerző 1997. április 10-én elhangzott McGinley előadásának a szerkesztett átirata.

Dulles, A. (2008): Az isteni gondviselés és az emberi szenvedés titka. Communio, 16(3-4): 91-99.

Dulles, A. (1968b): Bergamo, 1968. A Theological Reflection. Worldmission, 19: 17-28.

Dulles, A. (1985b): Bishops' Conference Documents. What Doctrinal Authority? Origins, 14(January 24): 528-534.

Dulles, A. (1990b): Catholicism and American Culture. The Uneasy Dialogue (Second Annual Fall McGinley Lecture, Fordham University Press, Bronx - New York, December 5, 1989). America, 162: $54-59$.

Dulles, A. (1986b): Catholicism and Catholicism. Concordia Theological Quarterly, 50: 81-94.

Dulles, A. (1986c): Catholicism and Democracy. The Catholic Mind, 49: 375-378.

Dulles, A. (1986d): Catholicism and Modernity. Horizons, 13: 375-378. doi: $10.1017 / \mathrm{s} 0360966900036410$

Dulles, A. (1983b): The Catholicity of the Augsburg Confession. Journal of Religion, 63: 337-354. doi: $10.1086 / 487060$

Dulles, A. (1950): Coming Home. In: J. A. O’BRIEN (ed.) (1950): Where I Found Christ. Doubleday \& Co., Garden City (NY), pp. 65-68.

DULLES, A. (1987c): art. Discipleship. In: M. ElIADE et al. (eds.) (1987): Encyclopedia of Religion. vol. 4., Macmillan, New York, pp. 361-364. 
Dulles, A. (1989a): Doctrinal Authority of Episcopal Conferences. In: TH. J. REESE (ed.) (1989): Episcopal Conferences. Historical, Canonical, and the Theological Studies. Georgetown University Press, Washington (WA), pp. 207-232.

Dulles, A. (1965): Ecumenical Dialogue and Apostolic Renewal. American Ecclesiastical Review, 153: $300-315$.

Dulles, A. (1980a): Ecumenism and Theological Method. Journal of Ecumenical Studies, 17: 40-48.

DULLES, A. (1978c): Ecumenism. Problems and Opportunities for the Future. In: D. TRASY; H. KÜNG \& J. B. MeTZ (eds.) (1978): Toward Vatican III. The Work That Needs to be Done. Seabury Press, New York, pp. 91-101.

Dulles, A. (1990c): Faith and Experience. Strangers? Rivals? Partners? The Priest, 46: 19-22.

DULLES, A. (1991a): Faith and Revelation. In: F. SCH. FIORENZA \& J. GALVIN (eds.) (1991): Systematic Theology. Roman Catholic Perspectives. Fortress Press, Minneapolis (MN), pp. 89-128.

Dulles, A. (1984a): Faith, Church, and God. Insights from Michael Polanyi. Theological Studies, 45: 537-550. doi:10.1177/004056398404500306

Dulles, A. (1970a): Faith, Reason, and the Logic of Discovery. Thought, 45: 485-502. doi:10.5840/thought197045433

DulLES, A. (1975): Finding God and the Hartford Appeal. America, 132: 334-337.

DuLLES, A. (1991b): From Symbol to System. A Proposal for Theological Method. Pro Ecclesia, 1: $42-$ 52. doi: $10.1177 / 106385129200100111$

DULLES, A. (1984b): Glorified Unorthodoxy' or Orthodoxy as Status Quo. Neither is Good for the Church. National Catholic Reporter, 20(July 20): 15.

Dulles, A. (1993a): Harvard as an Invitation to Catholicism. In: J. WILlS (ed.) (1993): The Catholics of Harvard Square. St. Bede's Publications, Petersham (MA), pp. 119-124.

DuLLES, A. (1968c): Hitünk és az új vélemények. Mérleg, 4(1): 49-51.

Dulles, A. (2000b): In Dialogue. Avery Dulles and Ladislas Orsy (on the papacy). America, 183(November 25): 13.

DULLES, A. (1976a): Intercommunion Between Lutherans and Roman Catholics. Journal of Ecumenical Studies, 13: 250-255.

Dulles, A. (1998a): Interview with Avery Dulles: The Finer Points of the Faith. National Catholic Register, (August 2-8) 1, 13.

Dulles, A. (1976b): Jewish-Christian Relations Since Vatican II. Problems and Prospects. The Catholic Mind, 74: 43-54.

DULles, A. (1992c): John Paul II and the New Evangelization. America, 166(February 1): 52-59, 6972.

Dulles, A. (1997c): John Paul II as a Theologian of Culture. Logos, 1: 19-33 doi:10.1353/log.1997.0022

DULleS, A. (1997d): John Paul II Theologian. Communio, 24: 723-724.

Dulles, A. (2002b): Krisztus a vallások között. Mérleg, 38(1): 15-26.

DuLLES, A. (2000c): Lehet-e keresztény a filozófia? Tanitvány, 6(2): 72-82.

DULles, A. (1988b): Lehramt und Unfehlbarkeit. In: W. KERN; H. J. POTTMEYER \& M. SECKLER (eds.) (1988): Handbuch der Fundamentaltheologie. Traktat Theologische Erkenntnislehre 4., Herder, Freiburg - Basel - Wien, pp. 153-178.

DuLLES, A. (1991c): Magisterium and Theological Method. Seminarium, 31(April - June): 289-299. 
Dulles, A. (1973a): Ministry and Intercommunion. Theological Studies, 34: 643-678. doi: $10.1177 / 004056397303400405$

Dulles, A. (1980b): Moderate Infallibilism. In: P. C. EMPIE et al. (eds.) (1980): Teaching Authority and Infallibility in the Church. Lutherans and Catholics in Dialogue 6., Augsburg Fortress Publ., Minneapolis (MN), pp. 81-100.

Dulles, A. (1991d): Nehézkes párbeszéd. Mérleg, 27(1): 32-44.

DuLLES, A. (1986e): On the Sense of the Faithful. America, 155: 240-242, 263.

DULles, A. (1980c): Revelation and Discovery. In: W. J. KeLLY (ed.) (1980): Theology and Discovery. Marquette University Press, Milwaukee (WI), pp. 1-29.

Dulles, A. (1999a): Second General Discussion. In: P. J. MuRnION (ed.) (1999): Church Authority in America Culture. The Second Cardinal Bernardin Conference. Crossroad Publ. Co., New York, p. 119, pp. 132-134.

Dulles, A. (1995b): Seven Essentials of Evangelization. Origins, 25(November 23): 397-400.

DulLES, A. (1999b): Tanúsítson-e bünbánatot az egyház? Mérleg, 35(1): 43-53.

Dulles, A. (1976c): Ten Principles of Ecumenism. Part I. New Covenant, 5: 29-33.

Dulles, A. (1976d): Ten Principles of Ecumenism. Part II. New Covenant, 6: 26-29.

Dulles, A. (1980d): The Augsburg Confession and the Contemporary Catholicism. In: J. A. BuRGESS (ed.) (1980): The Role of the Augsburg Confession. Catholic and Lutheran Views. Fortress Press, Philadelphia, pp. 131-138.

Dulles, A. (1994b): The Church, a Complex Reality. A Theologian Reflects on News Reporting. In: Religion and the Media (1994). Proceedings of a National Symposium Promoting Better News Coverage of Religion, Fadica, Washington (WA), pp. 39-46.

Dulles, A. (1973b): The Church and the Salvation. Missiology. An International Review, 71-80. doi: $10.1177 / 009182967300100208$

Dulles, A. (1991e): The Church as „One, Holy, Catholic and Apostolic”. One in Christ, 35: 12-26.

DulLes, A. (1993b): The Church as the Locus of Salvation. In: J. M. MCDERMOTT (ed.): The Thought of Pope John Paul II. Pontifical Gregorian University Press, Rome, pp. 170-187.

Dulles, A. (1971c): The Church is Communications. The Catholic Mind, 69: 6-16.

Dulles, A. (1982b): The Church. Sacrament and Ground of Faith. In: R. LATOURELLE \& G. O'COLLINS (eds.) (1982): Problems and Perspectives of Fundamental Theology. Paulist Press, New York, pp. 259-273.

Dulles, A. (1992d): The Church's Unity in Christ. Classical and Modern Views. In: D. BuRKE (ed.) (1992): Catholic Commission on Intellectual and Cultural Affairs. vol. 11., Philadelphia, pp. 1-13.

Dulles, A. (1972): The Church, the Churches, and the Catholic Church. Theological Studies, 33: 199234. doi:10.1177/004056397203300201

Dulles, A. (1966): The Constitution on Divine Revelation in Ecumenical Perspective. American Ecclesiastical Review, 154: 217-231.

Dulles, A. (1969b): The Contemporary Magisterium. Theology Digest, 17(Winter): 299-311.

DulLES, A. (1990d): The Decree of Ecumenism. Twenty-Five Years After. New Catholic World, 233: 196-201.

DULLES, A. (1985c): The Distinctive Role of Lutheranism. Lutheran Forum letter, 14: 7-8.

Dulles, A. (1992e): The Dogma of the Assumption. In: J. BuRGESS (ed.) (1992): The One Mediator, the Saints and Mary. Augsburg Fortress Publ., Minneapolis (MN), pp. 279-294. 
Dulles, A. (1984c): The Emerging World Church. A Theological Reflection. Proceedings of the Catholic Theological Society of America, 39: 1-12.

Dulles, A. (1984d): The Essence of Catholicism. Protestant and Catholic Perspectives. The Thomist, 48: 607-633. doi:10.1353/tho.1984.0004

Dulles, A. (1993c): The Four Faces of American Catholicism. Louvain Studies, 18: 99-109. doi:10.2143/ls.18.2.2013767

Dulles, A. (1997e): The Ignatian Charism and Contemporary Theology. America, 176(April 26): 1422.

Dulles, A. (1995c): The Lure of Catholicism. New Oxford Review, 52(March): 6-14.

Dulles, A. (1970b): The Magisterium and Authority in the Church. In: G. DEVINE (ed.) (1970): Theology in Revolution. Alba House, Staten Island (NY), pp. 29-45.

Dulles, A. (1978d): The Magisterium in History. A Theological Reflection. Chicago Studies, 17: 264281.

Dulles, A. (1991f): The Magisterium, Theology, and Dissent. Origins, 20(March 28): 692-696.

Dulles, A. (1974c): The Papacy. Bond or Barrier? Origins, 3(May 2): 705-712.

Dulles, A. (2000d): The Papacy for a Global Church. America, 183(July 15-22): 8-9.

Dulles, A. (1997f): The Pope and the Bishops. Who Leads and How? Review of R. R. GaILlardetz: Teaching with Authority. A Theology of the Magisterium in the Church. The Tablet, 251(June 28): 836-837.

Dulles, A. (1993d): The Prophetic Humanism of John Paul II. America, 169(October 23): 6-11.

Dulles, A. (1967b): The Protestant Contribution to Catholic Renewal. The Hartford Quarterly, 7: 717.

Dulles, A. (1960): The Protestant Preacher and the Prophetic Mission. Theological Studies, 21: 544580. doi: $10.1177 / 004056396002100402$

Dulles, A. (1988c): The Sources of Theology. In: BoYLE, J. P. \& G. KILCOURSE (eds.) (1988): The Sources of Theology. Essays on the Theme. Catholic Theological Society of America, Washington (WA). (introduction J. P. Boyle)

Dulles, A. (1968d): The Succession of Prophets in the Church. Concilium, 34: 52-62.

Dulles, A. (1964a): The Theology of Revelation. Theological Studies, 25: 43-58. doi: $10.1177 / 004056396402500103$

Dulles, A. (1980e): The Two Magisteria. An Interim Reflection. Proceedings of the Catholic Theological Society of America, 35: 155-169.

Dulles, A. (1998b): The Ways We Worship. First Things, 81(March): 28-34.

Dulles, A. (1992f): Theology and Worship. The Reciprocity of Prayer and Belief. Ex Auditu, 8: 85-94.

DuLLES, A. (1994c): Tradition and Creativity. In: K. HAGEN (ed.) (1994): Quadrilog. Tradition and the Future of Ecumenism. Essays in Honor of George H. Tavard. Liturgical Press, Collegeville (MN), pp. 312-327.

DULles, A. (1989b): University Theology as a Service to the Church. Thought, 64: 103-115. doi:10.5840/thought198964232

Dulles, A. (1976e): Unmasking Secret Infidelities. Hartford and the Future of Ecumenism. In: P. L. BERGER \& R. J. NEUHAUS (eds.) (1976): Against the World for the World. Seabury Press, New York, pp. 44-62.

DuLLES, A. (1993e): Vallás és a politika alakítása. Mérleg, 29(3): 280-290. 
Dulles, A. (1985d): Vatican II Reform. The Basic Principles. Church, 1: 3-10.

Dulles, A. (1979): What Belongs in a Future Ecumenical Creed? A Catholic Answer. In: H. KÜNG \& J. Moltmann (eds.) (1979): An Ecumenical Confession of Faith? Concilium 118., Seabury, New York, pp. 77-81.

2. Másodlagos források

Önálló müvek

Aввотт, W. M. (ed.) (1966): The Documents of Vatican II. America Press, New York.

CAREY, P. W. (2010a): Avery Cardinal Dulles, S.J. A Model Theologian (1918-2008). Paulist Press, Mahwah (NJ).

CONGAR, Y. (2015): Az egyház élő hagyománya. Tanulmány a hagyomány teológiai fogalmáról. Sensus Fidei Fidelium 6., L’Harmattan - Sapientia Szerzetesi Hittudományi Főiskola, Budapest.

CONGAR, Y. (2004): The Meaning of Tradition. Ignatius Press, San Francisco (CA).

CONGAR, Y. (1966): Tradition and Traditions. An Historical and a Theological Essay. Macmillan Co., New York.

CONGAR, Y. (1968²): Vraie et fausse réforme dans l'Église. Les Éditions du Cerf, Paris.

FLynN, G. (ed.) (2005): Yves Congar. Theologian of the Church. Peeters Publ., Louvain.

GaillardeTZ, R. R. (1997): Teaching with Authority. A Theology of the Magisterium in the Church. Liturgical Press, Collegeville (MN).

JANKIEWICZ, D. (2009): The Magisterium and Theologians in the Writings of Avery Dulles. The Conflicting Legacy of the Second Vatican Council. Verlag Dr. Müller, Saarbrücken.

KING, L. J. (2016): The Authoritative Weight of Non-Definitive Magisterial Teaching. The Catholic University of America, Washington (WA).

KIRMSE, A.-M.; M. M. CANARIS \& TH. E. MCCARRICK (eds.) (2011): The Legacy of Avery Cardinal Dulles, S.J. His Words and His Witness. Fordham University Press, New York.

KRÁNITZ, M. (2015): Alapvető hittan. Szent István Társulat, Budapest.

Mosley, L. (1978): Dulles. The Dial Press, New York.

Newman, J. H. (1989): An Essay on the Development of Christian Doctrine. University of Notre Dame Press, Notre Dame (IN).

Newman, J. H. (1985): On Consulting the Faith in Matters of Doctrine. Sheed and Ward, Kansas City (MO).

Nichols, T. L. (1997): That All May Be One. Hierarchy and Participation in the Church. Liturgical Press, Collegeville (MN).

OELRICH, A. (2011): Yves Congar's Vision of Ecclesial Authority. Liturgical Press, Collegeville (MN).

POLANYI, M. (1964): Personal Knowledge. Torchbooks 1158., Harper \& Row, New York.

POLÁNYI, M. (1994): Személyes tudás. 1-2. köt., Atlantisz Kiadó, Budapest.

SHECTERLE, R. A. (1996): The Theology of Revelation of Avery Dulles, 1980-1994. Symbolic, Meditation. Roman Catholic Studies 8., Edwin Mellen Press, Lewiston (NY) - Queenston Lampeter.

Sullivan, F. A. (1996): Creative Fidelity. Weighing and Interpreting Documents of the Magisterium. Paulist Press, New York. 
Sullivan, F. A. (2001): From Apostles to Bishops. The Development of the Episcopacy in the Early Church. Newman Press, New York.

Sullivan, F. A. (1983): Magisterium. Teaching Authority in the Catholical Church. Paulist Press, New York.

Sullivan, F. A. (1988): The Church We Believe In. One, Holy, Catholic, and Apostolic. Paulist Press, Mahwah (NJ).

Cikkek, kötetben megjelent tanulmányok

CAREY, P. W. (2010b): Cardinal Avery Dulles, S.J., Among the Theologians. A Memorial Reflection. Theological Studies, 71(4): 773-791. doi:10.1177/004056391007100401

CONGREGATION FOR THE DOCTRINE OF THE FAITH (1990): Donum veritatis. Instruction on the Ecclesial Vocation of the Theologian. Origins, 20(July 5): 117, 117-126.

CONGREGATION FOR THE DOCTRINE OF THE FAITH (1989): Profession of Faith. Origins, 18(March 16): 661- 663.

FORD, J. (2009): art. Avery Cardinal Dulles. In: W. J. MCDONALD \& MCGRAW-HILL (eds.) (2009): New Catholic Encyclopedia (Supplement). New York, p. 277.

GuARINO, T. G. (2009): Why Avery Dulles Matters. First Things, 20(May): 40-46.

JOHN PAUL II (1998): Ad tuendam fidem. Origins, 28(July 16): 113-116.

KeHL, M. (2003): Bíborosok vitája. Az egyetemes egyház és a helyi egyházak viszonyáról. Mérleg, 39(2): 169-186.

Massa, M. S. (2007): Avery Dulles, Teaching Authority in the Church, and the 'Dialectically Tense' Middle. An American Strategic Theology. Heythrop Journal, 48(6): 932-951. doi:10.1111/j.14682265.2007.00350.x

NEMZETKÖZI TEOLÓGiai BizotTSÁG (2016): A „sensus fidei” az egyház életében (2014). Athanasiana, 43: 7-61.

ÖRSY, L. (2000): The Papacy for an Ecumenical Age. A Response to Avery Dulles. America, 183(October 21): 9-15.

RATZINGER, J. \& T. BERTONE (1998): Commentary on the Profession of Faith's Concluding Paragraphs. Origins, 28(July 16): 116-119.

Sullivan, F. A. (2008): Review of A. Dulles: Magisterium. Teacher and Guardian of the Faith. Theological Studies, 69(3): 727. 